\title{
Prevalencija i učestalost konzumiranja psihoaktivnih tvari mladih u odgojnim ustanovama - razlike s obzirom na vrstu ustanove i znanje o psihoaktivnim tvarima
}

\author{
Neven Ricijaš \\ Odsjek za poremećaje u ponašanju \\ Edukacijsko-rehabilitacijski fakultet Sveučilišta u Zagrebu \\ $\checkmark$ E-mail:neven.ricijas@gmail.com \\ Valentina Kranželić \\ Odsjek za poremećaje u ponašanju \\ Edukacijsko-rehabilitacijski fakultet Sveučilišta u Zagrebu \\ Lorena Leskovar \\ Socijalna mentorica \\ Gradsko društvo Crvenog križa Krapina
}

\begin{abstract}
Sažetak
Istraživanja potvrđuju da adolescenti tijekom odrastanja eksperimentiraju s konzumacijom psihoaktivnih tvari, a glavni motivacijski procesi koji na to utječu vezani su uz želju da se ponašaju u skladu sa socijalnim normama, identitetom koji obilježava individualitet, bijegom od nelagode te samoregulacijom. Stavovi, uvjerenja i znanja o psihoaktivnim tvarima pokušavali su se dovesti u vezu s ponašanjima vezanima uz njihovu uporabu, međutim, rezultati istraživanja pokazuju slabu do umjerenu korelaciju.

Temeljni cilj ovog istraživanja stjecanje je uvida u učestalost konzumacije psihoaktivnih tvari mladih s problemima u ponašanju smještenim u odgojne ustanove, dok su specifični ciljevi istražiti razlike u učestalosti konzumacije s obzirom na vrstu ustanove, kao i s obzirom na razinu znanja o psihoaktivnim tvarima.

U istraživanju su sudjelovala ukupno $\mathrm{N}=74$ mladića smještena u sustavu pravosuđa (39,2\%) i socijalne skrbi (60,8\%). Dob sudionika kreće se od 14 do 21 godine (Mdob=16,90; SDdob=1,627). Korišteni instrumentarij je, uz osnovne sociodemografske podatke, ispitao znanja o psihoaktivnim tvarima te životnu i godišnju prevalenciju, kao i učestalost konzumiranja. Rezultati pokazuju nešto učestalije konzumiranje psihoaktivnih tvari mladih smještenih u sustavu pravosuđa, ali i mladih s višom razinom znanja o psihoaktivnim tvarima. Pritom je važno naglasiti da su efekti razlika niski do umjereni. Rezultati su interpretirani u kontekstu drugih domaćih i inozemnih prevalencijskih istraživanja te s obzirom na značaj znanja u kreiranju intervencija prema mladima u području prevencije konzumiranja psihoaktivnih tvari.
\end{abstract}

Ključne riječi: psihoaktivne tvari, droge, problemi u ponašanju, adolescenti, odgojna ustanova 


\section{Uvod}

Istraživanja niz godina potvrđuju da se adolescenti tijekom odrastanja susreću s eksperimentiranjem sa psihoaktivnim sredstvima, pri čemu su Krnić, Čorak i Modrić (2013) utvrdili da između 50\% i 60\% srednjoškolaca do kraja školovanja dođe u kontakt s nekom vrstom droga, a kao najčešći razlog konzumacije sami navode znatiželju, zabavu i utjecaj vršnjaka. Nedavni pregledi literature pokazuju da su glavni motivacijski procesi, koji utječu na konzumiranje psihoaktivnih tvari kod adolescenata, vezani uz želju da se ponašaju u skladu sa socijalnim normama, identitetom koji obilježava individualitet, bijegom od nelagode te samoregulacijom (Toumbourou i sur., 2007). Neki autori navode da je eksperimentiranje sa psihoaktivnim tvarima u adolescenciji očekivano ponašanje zbog neurobioloških značajki razvoja mozga u adolescenta, a koje se prije svega odnosi na nedovoljno razvijene funkcije prefrontalnog korteksa i intenzivniju aktivnost limbičkog sustava prilikom donošenja odluka (Bava, Tapert, 2010; Petras, Sloboda, 2014; Spear, 2000; Steinberg, Sheffield Morris, 2001; Steinberg, 2007; Volkow, Koob, McLellan, 2016). Pritom istraživanja jednoznačno potvrđuju da se radi o ponašanjima koja mogu prouzročiti značajnu štetu razvoju adolescenata u zdrave, odgovorne i zrele odrasle osobe (Bava, Tapert, 2010; Chambers, Taylor i Potenza, 2003, Monti i sur., 2005). Mnoga istraživanja o uporabi psihoaktivnih tvari provođena su na redovitoj populaciji adolescenata (primjerice ESPAD [http://www.espad.org] i HBSC [http://www.hbsc.org]) i donose podatke o životnoj prevalenciji kako slijedi: alkohol (92,3\%), cigarete (62,1\%), inhalanti (25,3\%), kanabis (21,5\%), lijekovi (za smirivanje ili sedativi) bez recepta liječnika (4,2\%) te ecstasy (2,4\%) (The European School Survey Project on Alcohol and Other Drugs [ESPAD], 2016). Ako je takva situacija s uporabom psihoaktivnih tvari u redovitoj populaciji, postavlja se pitanje, kakva je situacija kada je u pitanju specifična skupina mladih, onih s problemima u ponašanju te onih koji su zbog konzumacije i eksperimentiranja sa psihoaktivnim tvarima te zbog činjenja kaznenih djela smješteni u ustanove pravosuđa ili socijalne skrbi za mlade s problemima u ponašanju. Posebno zato što mnogi autori na uporabu psihoaktivnih tvari gledaju kao na kulminaciju problema u ponašanju koji se javljaju u djetinjstvu i ranoj adolescenciji u obliku smanjene kontrole ponašanja i opozicijskih ponašanja (Chassin, Ritter, Trim i King, 2003). Različita istraživanja te populacije adolescenata (Chassin, 2008; Horgan, 2013; Klatt, 2016; National Institute on Drug Abuse [NIDA], 2016; Putninš, 2009; Sutherland, Shepherd, 2001) ističu veću prevalenciju njihova konzumiranja kao i neke specifične rizične čimbenike u odnosu na opću populaciju mladih. Navedeno izaziva značajnu pozornost znanstvenika i stručnjaka u području rada s djecom i s mladima u riziku za razvoj problema u ponašanju ili s već razvijenim problemima u ponašanju, što dovodi do potrebe za ciljanim preventivnim i tretmanskim intervencijama.

Brlas (2010) psihoaktivnu tvar definira kao tvar koja djeluje na središnji živčani sustav na način da mijenja ne samo psihičko već i fizičko čovjekovo funkcioniranje. Budući da ne postoji jedna općeprihvaćena definicija psihoaktivnih tvari, u tablici 1 navedene su neke od najčešće korištenih. Zajedničko im je da se radi o kemijskim spojevima koji su prirodnog ili sintetskog podrijetla koji mijenja fizičke i psihičke procese konzumenta, a s druge strane nanosi štetu samoj osobi te može izazvati i stanje ovisnosti. 
Neven Ricijaš, Valentina Kranželić, Lorena Leskovar: Prevalencija i učestalost konzumiranja...

Tablica 1. Definicije psihoaktivnih tvari (Američka udruga psihijatara, 2014; Jukić, 2006; NIDA, 2016; Petz, 2005; Sakoman, 2009; Virno, 1979; World Health Organisation [WHO], 2016)

\begin{tabular}{|c|l|}
\hline IZVOR & \multicolumn{1}{c|}{ Definicija psihoaktivnih tvari } \\
\hline WHO (2016) & $\begin{array}{l}\text { - tvari koje kad su konzumirane, odnosno unesene u tjelesni sustav, utječu na mentalne procese kao što su } \\
\text { kognicija i afekti } \\
\text { ekvivalent nazivu psihotropne droge }\end{array}$ \\
\hline NIDA (2016) & $\begin{array}{l}\text { - kemijski spojevi koji utječu na cijelo tijelo i mijenjaju njegovu strukturu i funkciju te utječu na funkcioniranje } \\
\text { mozga }\end{array}$ \\
\hline Jukić (2006) & $\begin{array}{l}\text { - psihoaktivno sredstvo prirodnog ili sintetskog podrijetla koje se uzima da bi se postigla poželjna promjena } \\
\text { psihičkog, odnosno fizičkog stanja } \\
\text { cilj je postizanje psihološkog učinka, tj. otklanjanje neugode koja je nastala neuzimanjem tog sredstva, a o } \\
\text { kojem može postati i ovisna }\end{array}$ \\
\hline Sakoman (2009) & $\begin{array}{l}\text { - kemijske tvari koje su ili prirodnog ili umjetnog podrijetla, odnosno da su one vrste otrova psihoaktivnog } \\
\text { djelovanja čije trajnije konzumiranje može dovesti do stanja ovisnosti }\end{array}$ \\
\hline Petz (2005) & $\begin{array}{l}\text { psihoaktivne tvari djeluju na središnji živčani sustav te na taj način utječu na čovjekovo psihofizičko } \\
\text { funkcioniranje, odnosno na njegove psihičke procese poput mišljenja, osjeta, percepcije, govora i raspoloženja, } \\
\text { kao i na njegovo ponašanje } \\
\text { farmakološka sredstva koja djeluju na doživljavanje i ponašanje, a kao posljedicu mogu imati oštećenje } \\
\text { zdravlja, kako tjelesnog tako i psihičkog }\end{array}$ \\
\hline Virno (1979) & $\begin{array}{l}\text { - svaka psihotropna, odnosno psihoaktivna tvar, koja je ili prirodnog ili sintetskog podrijetla te se može } \\
\text { primjenjivati u terapeutske ili u neke druge svrhe, nemedicinske svrhe te koja može postati, ovisno o učincima } \\
\text { koji su joj svojstveni, načinu uzimanja, doziranja, učestalosti konzumiranja te ciljevima samog konzumenta, } \\
\text { otrovan i štetan čimbenik za samog pojedinca ili društvo, odnosno za cijeli navedeni sustav }\end{array}$ \\
\hline
\end{tabular}

Što se tiče kategorizacija psihoaktivnih tvari, postoji ih više. Neke razlikuju psihoaktivne tvari s obzirom na njihovo podrijetlo pa ih dijele na prirodne i sintetske. Prirodne psihoaktivne tvari u tom kontekstu obuhvaćaju proizvode biljnoga, životinjskog ili mineralnog podrijetla, dok su sintetske rezultat nekog kemijskog postupka. Drugi kriterij prema kojem se mogu podijeliti psihoaktivne tvari može biti njihovo djelovanje na središnji živčani sustav; razlikuju se psihostimulansi, psihodepresori ili depresanti, halucinogene tvari i kanabinoidi (Brlas, 2010). Bez obzira na podjele, kategorizacije i opis djelovanja psihoaktivnih tvari, važno je u obzir uzeti ključno, a to je znanstvena činjenica da se radi o tvarima koje utječu na fizičko, fiziološko, psihološko i ponašajno funkcioniranje čovjeka, posebno mladih ljudi čiji su neurobiološki i socijalno-emocionalni sustavi još u razvoju te time podložniji štetnim posljedicama uporabe navedenih tvari (Bava, Tapert, 2010; Chambers, Taylor, Potenza, 2003 Monti i sur., 2010).

U nastavku rada bit će prikazani rezultati nekih značajnijih istraživanja o prevalenciji uporabe psihoaktivnih tvari kod mladih opće populacije i onih s problemima u ponašanju, koji se zbog činjenja kaznenih djela nalaze u nekom obliku tretmana. Rezultati izabranih svjetskih i domaćih istraživanja detaljnije su tablično sistematizirani u privitku (Prilog 1. i Prilog 2.) gdje se nalaze informacije o autorima istraživanja, geografskom području ili zemlji u kojoj je provedeno istraživanje, uzorku te prevalenciji konzumiranja pojedinih psihoaktivnih tvari. Za ovu potrebu prikazana su istraživanja koja su provedena na obuhvatnijim ili nacionalno/regionalno reprezentativnim uzorcima.

Rezultati pokazuju da se prevalencija uporabe psihoaktivnih tvari odnosi na uporabu duhana/ cigareta, alkohola, marihuane i drugih droga, kao i legalnih psihoaktivnih tvari. Što se tiče uporabe cigareta, ESPAD-ovo istraživanje na 35 europskih zemalja (ESPAD, 2016) donosi podatak da je barem jedanput u životu cigarete pušilo $46 \%$ mladih, a u zadnjih 30 dana njih 33\%. Visoke vrijednosti spominju i afrička istraživanja koja navode $47,5 \%$ životne prevalencije uporabe duhana (The South African Medical Research Council [SAMRC], 2013) dok jedno azijsko istraživanje (WHO, 2003) navodi $32 \%$ životne prevalencije i $21,6 \%$ godišnje prevalencije uporabe cigareta kod mladih 
na Tajlandu. Mnogo niže vrijednosti bilježe istraživanja u drugim krajevima svijeta, pa tako The Substance Abuse and Mental Health Services Administration [SAMHSA], (2014) na uzorku mladih iz 50 američkih zemalja i Kolumbije nalazi da je mjesečna prevalencija uporabe cigareta tek 4,9\%, što je slično i podatcima Health Canada (2013) o 4\% mjesečne prevalencije i 13\% životne prevalencije uporabe cigareta. Australsko istraživanje (Centre for Behavioral Research, 2012) govori o 16,2\% godišnje prevalencije te $8,9 \%$ mjesečne, a duhan/cigarete je u zadnjem mjesecu konzumiralo/pušilo 10\% mladih iz 23 zemlje Južne i Srednje Amerike (Concise International Chemical Assessment Documents, [CICAD], 2015).

Što se tiče uporabe alkohola, iz prikazanih istraživanja vidljivo je da je alkohol češće konzumirana psihoaktivna tvar od cigareta pa se tako u ESPAD-ovu istraživanju na europskim podatcima (ESPAD, 2016) može vidjeti da je $80 \%$ mladih u životu pilo alkohol, a njih $48 \%$ u posljednjem mjesecu. U istom je istraživanju pronađeno da mladi iz Hrvatske to čine i češće, njih 92\% u životu, a 55\% u zadnjem mjesecu. Slične vrijednosti vidljive su u Kanadi gdje $41 \%$ mladih izvještava o uporabi alkohola u zadnjem mjesecu (Health Canada, 2013) te u zemljama Južne i Srednje Amerike gdje o tome izvještava 50\% mladih (CICAD, 2015). Nešto niže vrijednosti mjesečne prevalencije nalaze se kod mladih iz Australije gdje njih 29,1\% iskazuje uporabu alkohola u zadnjem mjesecu (Centre for Behavioral Research, 2012). Najmanju mjesečnu prevalenciju, od 11,5\%, moguće je uočiti u istraživanju SAMHSA (2014) koje uključuje mlade iz SAD-a i Kolumbije.

Kanabis je, kao ilegalno sredstvo ovisnosti, sljedeća najčešće konzumirana psihoaktivna tvar, a prevalencijska istraživanja govore o 16\% životne prevalencije u europskim zemljama dok je u Hrvatskoj taj podatak viši i iznosi 21\% (ESPAD, 2016). Sličan podatak životne prevalencije konzumiranja kanabisa, još i viši, nalazi se i u Kanadi i iznosi 23,9\% (Institute for Mental Health Policy Research, 2015). Ostala istraživanja navode godišnje prevalencije pa tako CICAD (2012) za mlade Južne i Srednje Amerike navodi 5\% - 20\% godišnje prevalencije, kanadsko istraživanje Health Canada (2013) navodi 19\%, australsko istraživanje (Centre for Behavioral Research, 2012) navodi $12 \%$, a afričko istraživanje SAMRC (2013) 13\% godišnje prevalencije konzumiranja marihuane među mladima.

Druge psihoaktivne tvari poput amfetamina, kokaina, heroina i slično konzumiraju se značajno manje pa se i prevalencijski podatci kreću u rasponu 1\% - 3\% kod europskih mladih (ESPAD, 2016; Steketee, Jonkman, Berten i Vettenburg, 2013) pa do 9,4 \% za ilegalne psihoaktivne tvari koje uključuju i kanabis SAD i Kolumbija (SAMHSA, 2014).

Zanimljivi su podatci i o novim psihoaktivnim tvarima, tzv. legalnim psihoaktivnim tvarima (primjerice lažni osvježivači zraka/soli za kupanje, Galaxy i slično), koji se nalaze u manjem broju istraživanja. U ovom području, životna prevalencija konzumacije mladih iz Hrvatske je $7 \%$, što je značajno više od $4 \%$ prosjeka prevalencije konzumacije iz 35 europskih zemalja (ESPAD, 2016). Nove se legalne psihoaktivne tvari u Kanadi konzumiraju značajno manje o čemu govori podatak o $1 \%$ godišnje prevalencije (Institute for Mental Health Policy Research, 2015).

Osim prikaza rezultata svjetskih i hrvatskih istraživanja, zanimljivo je istaknuti i podatak o kretanju konzumiranja psihoaktivnih tvari u Republici Hrvatskoj iz ponavljanih ESPAD-ovih istraživanja tijekom određenog vremena. Tako je ESPAD-ovo istraživanje iz 2015. godine (ESPAD, 2016) pokazalo pozitivne promjene kad je u pitanju konzumacija cigareta i alkohola u odnosu na ESPAD-ovo istraživanje iz 2011. godine (ESPAD, 2012), i u području životne i mjesečne prevalencije. Što se pak 
Neven Ricijaš, Valentina Kranželić, Lorena Leskovar: Prevalencija i učestalost konzumiranja...

tiče konzumacije drugih psihoaktivnih tvari, može se uočiti porast prevalencije kada je u pitanju konzumacija marihuane, odnosno kanabisa.

Budući da se u ovom radu predstavljaju rezultati istraživanja sa specifičnom populacijom mladih, onih s problemima u ponašanju smještenima u odgojne ustanove, vrijedno je prikazati istraživanja koja su provedena upravo s tom populacijom. $U$ privitku 2 nalaze se relevantna istraživanja kad je u pitanju populacija mladih koji su počinili neko kazneno djelo, odnosno koji su se u trenutku provođenja istraživanja nalazili u nekoj ustanovi ili su bili u nekom obliku probacije. Vidljivo je i da je riječ o europskim (Velika Britanija, Irska, Njemačka, itd.) i svjetskim istraživanjima (Australija, $S A D$, Afrika) dok hrvatskih istraživanja o tome nije bilo.

Iz pregleda tablice uočljive su značajno više vrijednosti prevalencijskih podataka za sve psihoaktivne tvari - alkohol i cigarete, a posebno za ilegalne poput kanabisa, heroina, kokaina, amfetamina i sličnog. Istaknimo podatak europskih istraživanja o $96 \%$ životne i $86 \%$ godišnje prevalencije uporabe ilegalnih psihoaktivnih tvari (Lader, Singleton i Meltzer, 2003) te 30\% mjesečne prevalencije (Klatt, 2016). Jedno australsko istraživanje (Putninš, 2001) navodi $81 \%$ mjesečne prevalencije za kanabis, a raspon od $10 \%-25 \%$ mjesečne prevalencije za ostale psihoaktivne tvari (inhalanti, stimulansi, narkotici, sedativi, halucinogeni) dok drugo australsko istraživanje navodi primjerice $46 \%$ životne prevalencije za amfetamine te $14 \%$ životne prevalencije za heroin (Kenny i Nelson, 2008). Tomu se mogu dodati i podatci o inhalantima s 37\% životne prevalencije te ecstasyju s 33\% životne prevalencije kod promatranog uzorka mladih počinitelja kaznenih djela iz Australije (Prichard i Payne, 2005). Slični podatci vidljivi su i u američkim istraživanjima koji govore o $85 \%$ životne prevalencije konzumacije kanabisa i 7\% - 25\% životne prevalencije za psihoaktivne tvari tipa ecstasyja, opijata, inhalanata, stimulansa, kokaina, sedativa i halucinogena (Mulvey, Schubert i Chassin, 2010).

Zanimljivo je i istraživanje Klattove (2016) provedeno na populaciji mladih u sukobu sa zakonom koje je pokazalo značajnu razliku u konzumaciji psihoaktivnih tvari s obzirom na vrstu ustanove u koju su smješteni, no nije bilo moguće zaključiti koje značajke ustanova utječu na ponašanje vezano za konzumaciju psihoaktivnih tvari te se u tom smjeru sugeriralo usmjeriti daljnja istraživanja. Istraživanje provedeno u Irskoj s mladima u sukobu sa zakonom (Horgan, 2013) pokazalo je da mladi s konzumacijom psihoaktivnih tvari započinju u dobi od 12 do 15 godina (medijan dobi započinjanja zlouporabe je 14 godina), a istraživanje navodi i da je više od $80 \%$ konzumacija psihoaktivnih tvari (najčešće je to bio alkohol) bilo povezano s počinjenjem kaznenog djela.

Istraživanje koje je proveo američki National Institute on Drug Abuse (NIDA, 2016) otkrilo je da je od svih maloljetnika, koji se nalaze u zatvoru, 90\% mladića i $80 \%$ djevojaka imalo poremećaje povezane s konzumacijom psihoaktivnih tvari u nekom životnom razdoblju. Slično potvrđuje i istraživanje Sittner Hartshorna, Whitbecka i Prenticea (2012) u SAD-u i Kanadi koje je pokazalo da su poremećaji vezani uz psihoaktivne tvari vrlo česti među adolescentima uključenima u kaznenopravni sustav te navode da oko $70 \%$ njih iz triju država SAD-a zadovoljava kriterije za mentalne poremećaje ili poremećaje vezane uz psihoaktivne tvari, a primjetne su i visoke stope mladih $\mathrm{s}$ dvama i više poremećaja.

Prilikom proučavanja ove teme, važan je i podatak o dobi prve konzumacije psihoaktivnih tvari jer rana inicijacija u rizična ponašanja, pa tako i konzumaciju psihoaktivnih tvari, može značiti i više problema, ozbiljnije posljedice i izrazito nepovoljne razvojne ishode (Kosterman, Hawkins, Guo, 
Catalano i Abbott, 2000), a posebno to vrijedi za mlade počinitelje kaznenih djela (King i Chassin, 2007). Longitudinalne studije adolescenata opće populacije u SAD-u pokazale su da prvo konzumiranje psihoaktivnih tvari počinje u ranoj ili srednjoj adolescenciji, zatim se povećava i vrhunac dostiže u dobi od 18 do 25 godina te potom opada u dvadesetim godinama, pri ulasku u odrasle uloge (Chen i Kandel, 1995; prema Mauricio i sur., 2009). Navodi se također da se kod maloljetnih počinitelja kaznenih djela, koji s konzumacijom počinju u vrlo ranim godinama, razvojni put konzumacije alkohola i kanabisa razlikuje od onog njihovih vršnjaka koji nisu činili kaznena djela (Grisso, 2004; prema Mauricio i sur., 2009). Tako u odnosu na svoje vršnjake, mladi počinitelji kaznenih djela, osim što imaju pet puta višu stopu uporabe psihoaktivnih tvari, imaju i tri puta višu stopu poremećaja povezanih s uporabom psihoaktivnih tvari).

U odnosu na etiologiju uporabe psihoaktivnih tvari i napredovanja privremene i povremene uporabe prema ozbiljnim problemima i poremećajima, istraživanja navode niz rizičnih i zaštitnih čimbenika (Cleveland, Feinberg, Bontempo i Greenberg, 2008; Stone, Becker, Huber i Catalano, 2012). Oni se uglavnom svrstavaju u ključne domene čovjekova biopsihosocijalnog funkcioniranja, kao i njegovih okruženja. U ovom će se radu pozornost posvetiti odnosu znanja i stavova/uvjerenja o psihoaktivnim tvarima i konzumiranju psihoaktivnih tvari, što je povezano s ciljem provedenog istraživanja.

Prema modelu znanje - stavovi - ponašanje, Ward i suradnici (2002) navode da promjene u ponašanju uključuju stjecanje prethodnog znanja, mijenjanje povezanih stavova te konačno mijenjanje ponašanja. Stavovi, uvjerenja i znanja u istraživanjima su se pokušavali dovesti u vezu s ponašanjima vezanima za uporabu psihoaktivnih tvari. Tako su istraživanja provedena u Kini (Han, Chen i Chen, 2011; Klink, Lin, Elkin, Strigenz i Liu 2011; Lin, Wu, Lai, Shi i Chu, 2010; Wen i suradnici, 2008) pokazala samo slabu povezanost između znanja o pušenju i ponašanja vezanog uz pušenje, dok su istraživanja iz zapadnih zemalja (Nobile, Anfosso, Pavia i Angelillo, 2000; Rutten, Augustson, Moser, Beckjord i Hesse 2008) pokazala da su bivši pušači dva puta svjesniji štetnosti pušenja nego trenutni pušači.

Istraživanja u Europi i svijetu navode da među mladima prevladavaju uglavnom pozitivni stavovi o psihoaktivnim tvarima, posebice alkoholu, cigaretama i kanabisu (Wibberly, 1997; Blue Moon Research and Planning, 2000; Redmond i Devaney, 2010). Što se tiče alkohola, većina ispitanika percipira ga kao pozitivno sredstvo koje povećava samopouzdanje i raspoloženje te koje im pomaže zaboraviti svakodnevne probleme (Redmond i Devaney, 2010). Navedeno potvrđuje i istraživanje u Danskoj (Miller, 2007) u kojem mladi konzumaciju alkohola opisuju kao socijalnu aktivnost te vlastitu konzumaciju povezuju uz načine izlazaka i zabave koje prakticiraju. Uz to, govore i o pritisku koji postoji među mladima gdje je pijenje usko povezano sa socijalizacijom i popularnošću, kao i sa statusom u socijalnoj skupini. Navedeno potvrđuju i brojna druga istraživanja (Andrews, Tildesley, Hops i Li, 2002; Elek, Miller-Day i Hecht, 2006; Ennett i suradnici, 2016). S druge strane, ti isti sudionici svjesni su posljedica koje nosi prekomjerno pijenje za odlučivanje, prosudbu te moguću agresiju i nasilje. I prema ilegalnim psihoaktivnim tvarima prevladava relativno pozitivan stav, posebice kad je u pitanju kanabis, za koji sudionici smatraju da bi trebao biti legaliziran, što se ne odnosi na ostale psihoaktivne tvari (Redmond i Devaney, 2010). Cosci, Zagà, Bertoli i Campiotti (2013) nalaze manjak znanja o pušenju i negativnim učincima pasivnog pušenja na zdravlje kod učenika opće populacije, a kao prediktore za rano započinjanje s pušenjem ističu gledanje učitelja i rođaka koji puše, utjecaj prijatelja i osjećaj inferiornosti. Isti autori navode da u općoj populaciji 
Neven Ricijaš, Valentina Kranželić, Lorena Leskovar: Prevalencija i učestalost konzumiranja...

nepušači imaju veća znanja o zdravstvenim rizicima i pasivnom pušenju u odnosu na pušače što bi moglo indicirati da znanje o cigaretama i posljedicama pušenja može pridonijeti manjoj uporabi cigareta, što pak nije potvrđeno u nekim drugim istraživanjima (Ganley i Rosario, 2013; Xu, Liu, Sharma i Zhau, 2015; Santos i suradnici, 2016). Točnije, posjedovanje znanja o psihoaktivnim tvarima i posljedicama njihova konzumiranja ne dovode se u korelaciju s manjim konzumiranjem, ali pozitivniji stavovi prema psihoaktivnim sredstvima mogu se povezati s većim konzumiranjem istih (Ganley i Rosario, 2013).

U odnosu na dostupne podatke iz literature moguće je zaključiti da mladi u velikoj mjeri smatraju da je konzumacija psihoaktivnih tvari izbor pojedinca (Redmond i Devaney, 2010). Uočljivi su i generalno pozitivni stavovi o kanabisu i alkoholu (Miller, 2007), a većina odobrava i povremenu uporabu kanabisa, smatrajući da ona nema neke iznimno štetne posljedice. Što se tiče ostalih psihoaktivnih tvari, stavovi variraju, međutim vidljiva je percepcija da su one ipak štetnije u odnosu na kanabis ili alkohol i cigarete (Blue Moon Research and Planning, 2000; Bryan, Moran, Farrell i O'Brien, 2000; Haddad, Shotar, Umlauf i Al- Zyoud, 2010).

Važno je istaknuti da istraživanja potvrđuju kako pozitivni stavovi i očekivanja od psihoaktivnih tvari mogu rezultirati povećanim rizikom za njihovu uporabu, kao i za tranziciju prema problematičnoj uporabi i problemima ovisnosti. Posebno snažni dokazi nalaze se za uporabu alkohola i cigareta (Early, 2005; Elliot, Orr, Watson i Jackson, 2005; Kosterman i sur., 2001; Tucker, Ellickson i Klein, 2003; prema Stone, Becker, Huber i Catalano, 2012), ali i za druge, ilegalne psihoaktivne tvari (Chassin i sur., 2003). Elek i suradnici (2006) navode niz istraživanja koja potvrđuju da su za uporabu psihoaktivnih tvari značajne norme, od onih socijalnih (kakve stavove o uporabi psihoaktivnih tvari imaju roditelji i vršnjaci) do osobnih (vlastitih stavova i uvjerenja o psihoaktivnim tvarima) te navode da je osobno favoriziranje uporabe psihoaktivnih tvari povezano s većom uporabom. Slično tome, Barkin, Smith i DuRant (2002) navode da je namjera konzumiranja psihoaktivnih tvari u budućnosti povezana s njihovom većom stvarnom uporabom.

$\mathrm{Na}$ kraju, dodat ćemo podatak o kretanju tržišta psihoaktivnih tvari kao okolinskom pokazatelju stanja. Europski centar za praćenje droga i ovisnosti (The European Monitoring Centre for Drugs and Drug Addiction [EMCDDA], 2016) u svojem godišnjem izvješću navodi da je europsko tržište psihoaktivnih tvari i dalje otporno, a prema određenim pokazateljima kanabis i stimulativne psihoaktivne tvari bilježe uzlazni trend. Ujedno se bilježi visoka čistoća, kao i potentnost nezakonitih tvari. Uz to, govori se i o složenosti tržišta jer se uza sve poznate ilegalne psihoaktivne tvari pojavljuje sve više novih psihoaktivnih tvari čiju je pojavu vrlo teško pratiti. Navedeno stavlja dodatni naglasak na potrebu sustavna provođenja istraživanja uporabe psihoaktivnih tvari s različitim populacijama djece, mladih i odraslih osoba, a da bi se za konzumiranje psihoaktivnih tvari i štetne posljedice, koje iz toga proizlaze, mogao ponuditi adekvatan preventivni i tretmanski odgovor na razini pojedinaca, obitelji, škole i zajednice, ali i, ne manje važno, na razini sustava, prije svega zakonske regulative i socijalnih politika.

Na tom je tragu i ovo istraživanje čiji je cilj bio ispitati prevalenciju i učestalost konzumiranja te znanja, stavove i uvjerenja mladih s problemima u ponašanju smještenima u ustanove pravosuđa ili socijalne skrbi. Pregledom literature primjetno je da istraživanja o ovome u hrvatskome pa čak i 
europskome kontekstu nedostaje te se ovim istraživanjem željelo dobiti početne istraživačke uvide i usmjeriti pozornost znanstvenicima i istraživačima na ovaj važan fenomen.

\section{Ciljevi istraživanja}

Temeljni cilj ovog istraživanja prevalencijskog je karaktera te se odnosi na stjecanje uvida u učestalost konzumacije psihoaktivnih tvari mladih s problemima u ponašanju smještenima u sustavu socijalne skrbi i sustavu pravosuđa. Dodatni su, specifični ciljevi, istražiti razlike u učestalosti konzumacije psihoaktivnih tvari s obzirom na vrstu ustanove, odnosno sustav u kojem su mladi smješteni, kao i s obzirom na njihovu razinu znanja o psihoaktivnim tvarima.

\section{Metodologija}

\section{Uzorak}

U istraživanju je sudjelovalo ukupno $\mathrm{N}=74$ mladića, pri čemu je njih $n=29(39,2 \%)$ bilo smješteno $u$ Odgojnom zavodu Turopolje, odnosno sustavu pravosuđa ( $n=29 ; 39,2 \%)$, a $n=45(60,8 \%)$ u Centru za pružanje usluga u zajednici Zagreb - Dugave (dislocirani Odjel smještaja) i Odgojnoj ustanovi Pahinsko u Ivancu, kao dvjema ustanovama iz sustava socijalne skrbi. Raspon dobi sudionika kreće se od 14 do 21 godine, pri čemu je prosječna dob Mdob=16,90 godina (SDdob=1,627) .

Provjerili smo postoje li razlike u dobi sudionika s obzirom na sustav unutar kojega su smješteni te rezultati $t$-testa pokazuju značajne razlike $(t=-4,68 ; p<, 001)$ na način da su mladići iz sustava socijalne skrbi (Mdob=16,12; SDdob=1,39) nešto mlađi (oko 1,5 godinu) u odnosu na mladiće smještene u sustavu pravosuđa (Mdob=17,79; SDdob=1,42).

Uzorak je prigodan iako je intencija istraživača bila obuhvatiti sve mladiće smještene u navedenim ustanovama, odnosno populaciju. Međutim, zbog nesistemskih čimbenika objektivnih razloga nedostupnosti mladića (primjerice bijeg iz ustanove, privremeni smještaj na drugoj lokaciji i slično), istraživanje je provedeno samo s mladićima koji su se u vrijeme provođenja istraživanja nalazili u ustanovi. Potrebno je naglasiti da su svi mladići, koji su bili dostupni u ustanovi, pristali sudjelovati u istraživanju, ali i da je pet upitnika isključeno iz daljnjih obrada zbog dojma istraživača o neprimjerenu ispunjavanju upitnika.

\section{Instrumentarij}

Za potrebe ovog istraživanja konstruiran je poseban anketni upitnik po uzoru na neke inozemne, već korištene instrumente (primjerice, Questionnaire used in Knowledge, Attitudes and Beliefs Survey (Bryan i sur., 2000), Vprašalnik za srednjošolce (Švajger, 2013), Substance use Questionnarie (Shild, 2016)).

Upitnik se sastojao od sljedećih dijelova:

1. Opći podatci o sudionicima istraživanja (vrsta ustanove i godine)

1 Napomena: podatak o dobi postoji za N = 62 sudionika istraživanja, a taj podatak nedostaje uglavnom za sudionike iz Odgojnog doma Pahinsko (Ivanec) koji su skrivanjem ove informacije željeli zadržati anonimnost prilikom ispunjavanja upitnika. 
Neven Ricijaš, Valentina Kranželić, Lorena Leskovar: Prevalencija i učestalost konzumiranja...

2. Upitnik znanja o psihoaktivnim tvarima

3. Upitnik o životnoj prevalenciji/učestalosti konzumiranja psihoaktivnih tvari

4. Upitnik o godišnjoj prevalenciji/učestalosti konzumiranja psihoaktivnih tvari.

Opći podatci o sudionicima istraživanja sastoje se od pitanja vezanih za dob i vrstu odgojne ustanove u koju su smješteni. Budući da je istraživanje provedeno u malim skupinama i na relativno malom uzorku sudionika, radi zaštite anonimnosti, što kraćeg trajanja ispunjavanja upitnika, ali i osjećaja sigurnosti samih sudionika, sociodemografske varijable nisu se detaljnije ispitivale.

Upitnik znanja o psihoaktivnim tvarima sastoji se od 20 pitanja koja se odnose na svojstva psihoaktivnih tvari, djelovanje, posljedice konzumiranja psihoaktivnih tvari te razvoj ovisnosti. Sudionici su odgovarali smatraju li određenu tvrdnju točnom, odnosno netočnom, a mogli su označiti i da ne znaju odgovor na postavljeno pitanje. Upitnik je kreiran temeljem različitih brošura i informativnih letaka namijenjenih mladima, a koji se distribuiraju u hrvatskim školama, zdravstvenim ustanovama ili drugim ustanovama za djecu i mlade. Na taj način istraživači su bili sigurni da upitnik (test) znanja sadrži pitanja primjerena populaciji, odnosno informacije o psihoaktivnim tvarima koje bi mladi trebali znati. Primjeri tvrdnji su: Katran je tvar u cigaretama koja izaziva ovisnost; Trava (marihuana) ne stvara ovisnost; Alkohol na svakoga djeluje jednako. Budući da je jedan od ciljeva ovog istraživanja i testiranje razlika u učestalosti konzumacije s obzirom na razinu znanja, ispitanici su prema medijanu (Med = 9) na ovom upitniku podijeljeni u dvije skupine.

Upitnik o životnoj/godišnjoj prevalenciji i učestalosti konzumiranja psihoaktivnih tvari sastoji se od 17 psihoaktivnih tvari koje se mogu kategorizirati u pet skupina: (1) Nikotin, (2) Alkohol, (3) llegalne psihoaktivne tvari (npr. speed, kokain, heroin), (4) "Legalne" psihoaktivne tvari/nove droge (npr. lažni osvježivači prostora, Galaxy, Atomix), (5) Lijekovi i inhalanti (npr. Xanax, Normabel, Apaurin). Radi se o dvama odvojenim upitnicima, s istom uputom sudionicima, ali različitim vremenskim okvirom na koji se odnosi učestalost konzumacije. Prvi se odnosi na životnu, a drugi na godišnju prevalenciju/učestalost. Postavljeno pitanje bilo je: Jesi li ikada u životu / u posljednjih godinu dana probao ili konzumirao određenu tvar, i ako da, koliko puta? Ponuđena je ljestvica odgovora od pet stupnjeva (nikada; 1 - 2 puta; 3 - 4 puta; 5 - 10 puta; 10 i više puta).

\section{Postupak provedbe istraživanja}

Istraživanje je provedeno 2016. godine uz pismenu suglasnost Ministarstva pravosuđa i Ministarstva socijalne politike i mladih, kao i Etičkog povjerenstva Edukacijsko-rehabilitacijskog fakulteta Sveučilišta u Zagrebu. Korištena je metoda papir-olovka ispunjavanja upitnika u vrlo malim skupinama ili parovima. Ispunjavanje upitnika u potpunosti je bilo prilagođeno svakom sudioniku na način da mu se upitnik čitao ako je bilo potrebno. Prosječno vrijeme ispunjavanja upitnika bilo je 20 minuta. Svi su sudionici prije istraživanja bili usmeno informirani o svrsi, osnovnom cilju i postupcima istraživanja, kao i o dobrovoljnosti njihova sudjelovanja, anonimnosti te načinima zaštite privatnosti podataka i identiteta te mogućim rizicima. Potrebno je naglasiti da je sudionicima jasno naznačeno da nitko od zaposlenika ustanova u kojima su smješteni neće imati uvid u njihove odgovore te da u bilo kojem trenutku mogu odustati od sudjelovanja u istraživanju. Sudionici iz Odgojnog zavoda Turopolje dali su pisani, a sudionici u sustavu socijalne skrbi usmeni pristanak na sudjelovanje. Budući 
da su svi sudionici istraživanja stariji od 14 godina života, ovakav način provedbe istraživanja, kao i svi drugi elementi, u skladu su s Etičkim kodeksom istraživanja s djecom (2005).

\section{Metode obrade podataka}

Za potrebe ostvarivanja ciljeva ovog rada, uz deskriptivnu statistiku (mjere središnjih vrijednosti i frekvencije odgovora) korišten je Mann-Whitneyjev $U$-test $s$ računanjem veličine efekta $(r=Z / \sqrt{ } N)$.

\section{Rezultati i rasprava}

životna prevalencija govori nam o iskustvu konzumacije psihoaktivnih tvari tijekom cijelog života. Iz rezultata u tablici 2 uočavamo da su gotovo svi sudionici ovog istraživanja konzumirali cigarete i alkoholna pića, a u odnosu na učestalost konzumacije uočavamo dominantnu frekvenciju od deset puta ili više tijekom života. S obzirom na ovakvu učestalost životne konzumacije, ne iznenađuje rezultat o nepostojanju razlika između mladih s obzirom na vrstu ustanove. Kod godišnje prevalencije (Tablica 3.) zamjetna je nešto niža, ali opet relativno visoka prevalencija konzumacije, međutim, mladi u odgojnom zavodu češće su konzumirali cigarete $(p<, 050 ; r=, 27)$, dok su mladi u sustavu socijalne skrbi nešto češće konzumirali pivo $(p<, 010 ; r=, 29)$, pri čemu je vidljivo da su efekti razlika mali.

U odnosu na ilegalne psihoaktivne tvari, životna je prevalencija najizraženija za konzumiranje marihuane na način da je oko $70 \%$ mladih u ustanovama socijalne skrbi, te više od $90 \%$ mladih u odgojnom zavodu, barem jednom u životu konzumiralo marihuanu pa je razlika značajna i u učestalosti $(p<, 050 ; r=, 25)$. Razlike su također utvrđene i za konzumaciju kokaina $(p<, 050 ; r=, 27)$ te metadona $(p<, 001 ; r=, 56)$ na način da su ih mladi iz odgojnog zavoda tijekom života češće konzumirali, pri čemu su efekti razlike kod metadona veliki. Neovisno o dobivenim razlikama i veličini efekta, rezultati istraživanja životne prevalencije ilegalnih psihoaktivnih tvari u ovom su istraživanju prilično visoki, bez obzira na ustanovu. Činjenica da je oko 33\% mladih u sustavu socijalne skrbi te oko 55\% njih iz odgojnog zavoda probalo speed/amfetamine ili ecstasy (MDMA) zabrinjavajuća je te značajno viša od rezultata opće populacije mladih u Hrvatskoj, kao i činjenica da je oko $20 \%$ mladih u ovom istraživanju tijekom života probalo LSD.

I u području godišnje prevalencije (Tablica 3.) konzumacija metadona kod mladih iz odgojnog zavoda izrazito je visoka (preko 50\%) te je nejasno radi li se o liječnički propisanom metadonu ili zlouporabi te psihoaktivne tvari. Isto je potrebno spomenuti i u odnosu na pitanja o konzumaciji tableta. lako su sudionici istraživanja dobili uputu da se kod istraživanja konzumacije lijekova pitanje odnosi na zlouporabu lijekova, dakle njihovo korištenje bez liječničkog recepta, a radi psihoaktivna učinka, ne možemo biti sigurni jesu li svi sudionici na taj način pristupili odgovaranju. Ipak, odgovori i životne i godišnje prevalencije ukazuju da je zlouporaba lijekova učestalija kod mladih u sustavu pravosuđa u odnosu na mlade smještene u sustavu socijalne skrbi, pri čemu su efekti tih razlika umjereni. Isto je i za godišnju prevalenciju lažnih osvježivača prostora koju je tijekom prošle godine koristilo oko $30 \%$ mladih iz domova socijalne skrbi, u odnosu na čak $80 \%$ mladih iz odgojnog zavoda, što je naravno značajna razlika s prilično velikim efektom $(p<, 001 ; r=, 46)$. 
Generalno, rezultati pokazuju nešto učestaliju konzumaciju psihoaktivnih tvari mladih smještenih u odgojnom zavodu, što je bilo i očekivano budući da se radi o rizičnijoj i nešto starijoj populaciji mladih. Dobiveni rezultati u području prevalencije konzumiranja psihoaktivnih tvari u skladu su s mnogim ranije navedenim europskim i svjetskim istraživanjima (Chassin, 2008; Horgan, 2013; Klatt, 2016; NIDA, 2016; Putninš, 2009; Sittner Hartshorn, Whitbeck, Prentice, 2012; Sutherland, Shepherd, 2001;) koja navode da su mladi s problemima u ponašanju, koji su u nekom obliku tretmana u zajednici ili kaznenom sustavu, u većem riziku za konzumiranje psihoaktivnih tvari. Osim toga, navedeni izvori ističu i veću vjerojatnost nepovoljne tranzicije od eksperimentiranja i povremene uporabe prema trajnoj uporabi, ovisnosti i psihosocijalnim problemima povezanim $s$ konzumiranjem psihoaktivnih tvari kod promatrane populacije mladih. 
Kriminologija i socijalna integracija Vol 27 (2019) 1, 3 - 34.

Tablica 2.: Životna prevalencija konzumiranja psihoaktivnih tvari i razlike u učestalosti konzumacije s obzirom na sustav smještaja (Mann-Whitneyjev U-test)

\begin{tabular}{|c|c|c|c|c|c|c|c|c|c|c|c|}
\hline & \multirow{2}{*}{$\begin{array}{l}\text { Životna } \\
\text { prevalencija } \\
\text { konzumiranja }\end{array}$} & \multirow{2}{*}{ Ustanova } & \multicolumn{5}{|c|}{$\%$} & \multirow{2}{*}{ PR } & \multirow{2}{*}{ MWU } & \multirow{2}{*}{$\mathbf{p}$} & \multirow{2}{*}{$\mathbf{r}$} \\
\hline & & & Nikad & $1-2 x$ & $3-4 X$ & $5-10 x$ & $10 X<$ & & & & \\
\hline \multirow{2}{*}{ Nikotin } & \multirow{2}{*}{ Cigarete } & SOC.SKRB. & 4,8 & 0,0 & 4,8 & 2,4 & 88,1 & 34,73 & \multirow{2}{*}{555,0} & \multirow{2}{*}{$>, 050$} & \\
\hline & & PRAVOS. & 0,0 & 0,0 & 0,0 & 3,4 & 96,6 & 37,84 & & & \\
\hline \multirow{6}{*}{ Alkohol } & \multirow{2}{*}{ Pivo } & SOC.SKRB. & 4,8 & 7,1 & 4,8 & 2,4 & 81,0 & 36,26 & \multirow{2}{*}{556,0} & \multirow{2}{*}{$>, 050$} & \\
\hline & & PRAVOS. & 3,6 & 10,7 & 7,1 & 3,6 & 75,0 & 34,36 & & & \\
\hline & \multirow{2}{*}{ Vino } & SOC.SKRB. & 4,8 & 11,9 & 4,8 & 2,4 & 76,2 & 36,20 & \multirow{2}{*}{600,5} & \multirow{2}{*}{$>, 050$} & \\
\hline & & PRAVOS. & 3,4 & 6,9 & 6,9 & 10,3 & 72,4 & 35,71 & & & \\
\hline & \multirow{2}{*}{$\begin{array}{l}\text { Žestoka pića (npr. } \\
\text { votka, džin, viski) }\end{array}$} & SOC.SKRB. & 9,5 & 4,8 & 4,8 & 11,9 & 69,0 & 35,56 & \multirow{2}{*}{590,5} & \multirow{2}{*}{$>, 050$} & \\
\hline & & PRAVOS. & 3,4 & 13,8 & 3,4 & 6,9 & 72,4 & 36,64 & & & \\
\hline \multirow{20}{*}{$\begin{array}{l}\text { llegalne } \\
\text { psihoaktivne } \\
\text { tvari }\end{array}$} & \multirow{2}{*}{ Marihuana } & SOC.SKRB. & 33,3 & 7,1 & 2,4 & 9,5 & 47,6 & 32,19 & \multirow{2}{*}{449,0} & \multirow{2}{*}{$<, 050$} & 25 \\
\hline & & PRAVOS. & 6,9 & 17,2 & 3,4 & 3,4 & 69,0 & 41,52 & & & , \\
\hline & Hǎ̌šš & SOC.SKRB. & 54,8 & 7,1 & 2,4 & 2,4 & 33,3 & 32,42 & 4585 & $>050$ & \\
\hline & Masis & PRAVOS. & 27,6 & 17,2 & 0,0 & 6,9 & 48,3 & 41,19 & 430,5 & , & \\
\hline & Sno & SOC.SKRB. & 66,7 & 7,1 & 7,1 & 0,0 & 19,0 & 32,62 & 1670 & $3=050$ & \\
\hline & speed/amfetamını & PRAVOS. & 44,8 & 10,3 & 3,4 & 6,9 & 34,5 & 40,90 & $46 /, 0$ & $\$, 050$ & \\
\hline & Kokain & SOC.SKRB. & 78,6 & 9,5 & 2,4 & 2,4 & 7,1 & 32,17 & 4480 & $<050$ & 27 \\
\hline & Kokain & PRAVOS. & 51,7 & 17,2 & 17,2 & 3,5 & 10,3 & 41,55 & 448,0 & $<, 050$ & , 21 \\
\hline & Ecstasy (MDMA, & SOC.SKRB. & 66,7 & 9,5 & 2,4 & 4,8 & 16,7 & 32,79 & 4740 & $>050$ & \\
\hline & „bomb & PRAVOS. & 44,8 & 10,3 & 3,4 & 17,2 & 24,1 & 40,66 & $4 \pi 4,0$ & (3,050 & \\
\hline & 150 & SOC.SKRB. & 80,5 & 4,9 & 4,9 & 0,0 & 9,8 & 34,83 & 5670 & $>050$ & \\
\hline & LSD & PRAVOS. & 78,6 & 3,6 & 3,6 & 14,3 & 0,0 & 35,25 & 301,0 & 3,050 & \\
\hline & Hernin & SOC.SKRB. & 95,2 & 2,4 & 0,0 & 0,0 & 2,4 & 34,19 & 5330 & $>050$ & \\
\hline & HeroIn & PRAVOS. & 85,7 & 10,7 & 0,0 & 0,0 & 3,6 & 37,46 & 333,0 & 3,050 & \\
\hline & Ketamin & SOC.SKRB. & 92,5 & 0,0 & 2,5 & 0,0 & 5,0 & 31,11 & 424.5 & $>050$ & \\
\hline & Netaminn & PRAVOS. & 73,1 & 11,5 & 7,7 & 0,0 & 7,7 & 37,17 & $4<4,3$ & 3,050 & \\
\hline & ICE (metamfetamin, & SOC.SKRB. & 97,6 & 0,0 & 0,0 & 0,0 & 2,4 & 33,87 & & & \\
\hline & „meth“) & PRAVOS. & 89,3 & 3,6 & 0,0 & 3,6 & 3,6 & 36,66 & 527,5 & $>, 050$ & \\
\hline & Metadon, & SOC.SKRB. & 85,4 & 7,3 & 2,4 & 0,0 & 4,9 & 27,13 & & & \\
\hline & $\begin{array}{l}\text { Subutex, } \\
\text { Suboxone }\end{array}$ & PRAVOS. & 32,1 & 17,9 & 3,6 & 7,1 & 39,3 & 46,52 & 251,5 & $<, 001$ &, 56 \\
\hline "Legalne"/ & Lažni osvježivači & SOC.SKRB. & 52,4 & 11,9 & 2,4 & 7,1 & 26,2 & 29,07 & & & \\
\hline $\begin{array}{l}\text { Nove } \\
\text { psihoak. tvari }\end{array}$ & $\begin{array}{l}\text { prostora (npr. } \\
\text { Galaxy, Atomix) }\end{array}$ & PRAVOS. & 10,3 & 10,3 & 6,9 & 13,8 & 58,6 & 46,03 & 318,0 & 3,050 & \\
\hline & Tablete & SOC.SKRB. & 53,7 & 4,9 & 9,8 & 9,8 & 22,0 & 30,35 & & & \\
\hline Lijekovi i & $\begin{array}{l}\text { (anksiolitici/ } \\
\text { sedativi/hipnotici) }\end{array}$ & PRAVOS. & 20,7 & 17,2 & 0,0 & 17,2 & 44,8 & 42,78 & 383,5 & $<, 010$ &, 32 \\
\hline & Inhalanti (ljepilo, & SOC.SKRB. & 95,0 & 0,0 & 0,0 & 0,0 & 5,0 & 31,85 & 4540 & $<050$ & 27 \\
\hline & aceton, boje) & PRAVOS. & 75,0 & 10,7 & 10,7 & 0,0 & 3,6 & 38,29 & 454,0 & 2,050 &, 2 \\
\hline
\end{tabular}

Legenda: Ustanova = sustav u čijoj je nadležnosti ustanova; Soc.Skrb = socijalna skrb; Pravos. = pravosuđe; $P R=$ prosječni rang; $M W U=$ Mann-Whitneyjev U-test; $p=$ značajnost; $r$ = veličina efekta; masnim slovima označene značajne razlike 
Neven Ricijaš, Valentina Kranželić, Lorena Leskovar: Prevalencija i učestalost konzumiranja...

Tablica 3.: Godišnja prevalencija konzumiranja psihoaktivnih tvari i razlike u učestalosti konzumacije s obzirom na sustav smještaja (Mann-Whitneyjev U-test)

\begin{tabular}{|c|c|c|c|c|c|c|c|c|c|c|c|}
\hline & \multirow{2}{*}{$\begin{array}{l}\text { Godišnja } \\
\text { prevalencija } \\
\text { konzumiranja }\end{array}$} & \multirow{2}{*}{ Ustanova } & \multicolumn{5}{|c|}{$\%$} & \multirow{2}{*}{ PR } & \multirow{2}{*}{ MWU } & \multirow{2}{*}{$\mathbf{p}$} & \multirow{2}{*}{$\mathbf{r}$} \\
\hline & & & Nikad & $1-2 x$ & $3-4 x$ & $5-10 x$ & $10 X<$ & & & & \\
\hline \multirow{2}{*}{ Nikotin } & \multirow{2}{*}{ Cigarete } & SOC.SKRB. & 9,3 & 2,3 & 2,3 & 2,3 & 83,7 & 34,14 & \multirow{2}{*}{522,0} & \multirow{2}{*}{$<, 050$} & \multirow{2}{*}{27} \\
\hline & & PRAVOS. & 0,0 & 0,0 & 0,0 & 0,0 & 100,0 & 40,00 & & & \\
\hline \multirow{6}{*}{ Alkohol } & \multirow{2}{*}{ Pivo } & SOC.SKRB. & 7,3 & 7,3 & 9,8 & 4,9 & 70,7 & 39,94 & \multirow{2}{*}{412,5} & \multirow{2}{*}{$<, 010$} & \multirow{2}{*}{29} \\
\hline & & PRAVOS. & 31,0 & 10,3 & 3,4 & 10,3 & 44,8 & 29,22 & & & \\
\hline & \multirow{2}{*}{ Vino } & SOC.SKRB. & 12,2 & 7,3 & 9,8 & 4,9 & 65,9 & 37,24 & \multirow{2}{*}{482,0} & \multirow{2}{*}{$>, 050$} & \\
\hline & & PRAVOS. & 25,0 & 14,3 & 0,0 & 7,1 & 53,6 & 31,71 & & & \\
\hline & \multirow{2}{*}{$\begin{array}{l}\text { Žestoka pića (npr. } \\
\text { votka, džin, viski) }\end{array}$} & SOC.SKRB. & 16,7 & 9,5 & 11,9 & 7,1 & 54,8 & 37,75 & \multirow{2}{*}{535,5} & \multirow{2}{*}{$>, 050$} & \\
\hline & & PRAVOS. & 27,6 & 13,8 & 6,9 & 3,4 & 48,3 & 33,47 & & & \\
\hline \multirow{20}{*}{$\begin{array}{l}\text { llegalne } \\
\text { psihoaktivne } \\
\text { tvari }\end{array}$} & \multirow{2}{*}{ Marihuana } & SOC.SKRB. & 42,9 & 4,8 & 9,5 & 4,8 & 38,1 & 33,93 & 5220 & 7050 & \\
\hline & & PRAVOS. & 27,6 & 6,9 & 6,9 & 13,8 & 44,8 & 39,00 & & (200 & \\
\hline & Hح̌̌̌̆̌ & SOC.SKRB. & 63,4 & 9,8 & 0,0 & 2,4 & 24,4 & 34,49 & 5520 & 7050 & \\
\hline & 然asis & PRAVOS. & 63,0 & 7,4 & 0,0 & 7,4 & 22,2 & 34,52 & ה & , & \\
\hline & & SOC.SKRB. & 76,2 & 2,4 & 2,4 & 4,8 & 14,3 & 34,23 & & & \\
\hline & 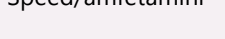 & PRAVOS. & 62,1 & 6,9 & 10,3 & 3,4 & 17,2 & 38,57 & 年 & (2000 & \\
\hline & Kolanin & SOC.SKRB. & 83,3 & 7,1 & 0,0 & 2,4 & 7,1 & 34,48 & 5150 & 7050 & \\
\hline & Nunain & PRAVOS. & 72,4 & 10,3 & 3,4 & 6,9 & 6,9 & 38,21 & (4) & , & \\
\hline & Ecstasy (MDMA, & SOC.SKRB. & 73,8 & 7,1 & 4,8 & 4,8 & 9,5 & 35,02 & 5680 & $>050$ & \\
\hline & „bomboni“) & PRAVOS. & 69,0 & 0,0 & 13,8 & 0,0 & 17,2 & 37,41 & 300,0 & (2000 & \\
\hline & ISD & SOC.SKRB. & 83,3 & 11,9 & 0,0 & 0,0 & 4,8 & 36,33 & 5950 & $>050$ & \\
\hline & (50) & PRAVOS. & 86,2 & 3,4 & 6,9 & 3,4 & 0,0 & 35,52 & 每 & (2000 & \\
\hline & Hornin & SOC.SKRB. & 97,7 & 2,3 & 0,0 & 0,0 & 0,0 & 34,31 & 520.5 & 7050 & \\
\hline & 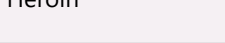 & PRAVOS. & 85,7 & 10,7 & 0,0 & 3,6 & 0,0 & 38,59 & (3) & (2,050 & \\
\hline & Kotamin & SOC.SKRB. & 95,2 & 0,0 & 0,0 & 0,0 & 4,8 & 35,24 & 5770 & $>050$ & \\
\hline & (1) & PRAVOS. & 89,7 & 6,9 & 0,0 & 0,0 & 3,4 & 37,10 & 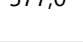 & (20) & \\
\hline & ICE (metamfetamin, & SOC.SKRB. & 97,6 & 0,0 & 0,0 & 0,0 & 2,4 & 34,86 & 5610 & $>050$ & \\
\hline & „meth") & PRAVOS. & 92,9 & 0,0 & 0,0 & 7,1 & 0,0 & 36,46 & 301,0 & (2) & \\
\hline & Metadon, & SOC.SKRB. & 93,0 & 2,3 & 2,3 & 0,0 & 2,3 & 29,88 & & & \\
\hline & Suboxone & PRAVOS. & 48,3 & 13,8 & 3,4 & 3,4 & 31,0 & 46,31 & (2) & 2,001 & (00) \\
\hline "Legalne"/ & Lažni osvježivači & SOC.SKRB. & 69,0 & 9,5 & 2,4 & 2,4 & 16,7 & 28,67 & & & \\
\hline psihoak. tvari & $\begin{array}{l}\text { prostora (npr. } \\
\text { Galaxy, Atomix) }\end{array}$ & PRAVOS. & 20,7 & 3,4 & 13,8 & 24,1 & 37,9 & 46,62 & 301,0 & $<, 001$ & 46 \\
\hline & & SOC.SKRB. & 66,7 & 9,5 & 11,9 & 0,0 & 11,9 & 31,43 & & & \\
\hline Lijekovi i & sedativi/hipnotici) & PRAVOS. & 41,4 & 10,3 & 3,4 & 6,9 & 37,9 & 42,62 & 411,0 & 2,050 & (50, \\
\hline & Inhalanti (ljepilo, & SOC.SKRB. & 95,3 & 2,3 & 0,0 & 0,0 & 2,3 & 36,69 & 6155 & $\lambda{ }^{\prime}$ & \\
\hline & acet & PRAVOS. & 96,6 & 3,4 & 0,0 & 0,0 & 0,0 & 36,22 & 年 & , & \\
\hline
\end{tabular}

Legenda: Ustanova = sustav u čijoj je nadležnosti ustanova; Soc.Skrb = socijalna skrb; Pravos. = pravosuđe; PR = prosječni rang; $M W U=$ Mann-Whitneyjev U-test; $p$ = značajnost; $r$ = veličina efekta; masnim slovima označene značajne razlike

S obzirom na to da nas u ovom istraživanju zanimaju razlike u životnoj i godišnjoj prevalenciji te učestalosti konzumacija psihoaktivnih tvari mladih, s obzirom na njihovu razinu znanja, provjerili smo postoje li razlike u znanju mladića između ovih dvaju sustava. Rezultati t-testa pokazuju da između njih ne postoje razlike na ukupnom rezultatu testa znanja o psihoaktivnim tvarima ( $\mathrm{t}=$ $1,18 ; p>, 050)$. Dodatno smo u dvije skupine podijelili sve mladiće $s$ obzirom na medijan (Med=9) ukupnog rezultata testa znanja na one koji imaju manje $(n=39)$ i koji imaju više znanja $(n=35)$, te rezultati hi-kvadrat testa također potvrđuju da ne postoje razlike u razini znanja između onih smje- 
štenih u sustavu pravosuđa i onih u sustavu socijalne skrbi $\left(\chi^{2}=2,45 ; p>, 050\right)$. Provjerili smo postoji li razlika u dobi između mladića s više znanja ili manje znanja, budući da je već ranije navedeno da su mladići smješteni u Odgojnom zavodu Turopolje nešto stariji od onih u sustavu socijalne skrbi. Međutim, rezultati t-testa pokazuju da nema razlike u njihovoj dobi $(t=0,015 ; p>, 050)$ te je prosječna dob obiju skupina Mdob=16,9 godina.

Rezultati prikazani u tablicama 4 i 5 pokazuju da na pojedinim varijablama, odnosno pojedinim sredstvima ovisnosti postoje značajne razlike, i to na način da mladi s većom općom razinom znanja o psihoaktivnim tvarima češće konzumiraju sredstva ovisnosti. Uz vina i žestoka pića, kao legalna sredstva ovisnosti, uočavamo da su mladi s većom razinom znanja tijekom svojeg života češće konzumirali hašiš $(p<, 001 ; r=, 35)$, speed/amfetamine $(p<, 050 ; r=, 23)$, kokain $(p<, 010 ; r=, 34)$ i ICE ( $p<, 050 ; r=, 26)$, odnosno hašiš $(p<, 050 ; r=, 27)$ i ecstasy $(p<, 050 ; r=, 27)$ tijekom prošle godine. Valja napomenuti da su razlike u svim navedenim umjerene i kreću se oko $r=, 30$, što je zapravo vrlo slično efektima razlika u odnosu na vrstu ustanove (sustav smještaja).

Pregledi literature usmjerene proučavanju programa prevencije konzumiranja psihoaktivnih tvari kod adolescenata ukazuju na činjenicu da informacije i znanje o psihoaktivnim sredstvima kao jedine i samostalne preventivne strategije nisu dovoljne za prevenciju inicijacije u konzumiranje Hansen (1992; prema Toumbourou i suradnici, 2007). Slično tome, Barnea, Teichman i Rahav (1992) su u longitudinalnom testiranju integrativnog modela uporabe psihoaktivnih tvari kod mladih dokazali da od kognitivnih varijabli ulogu u konzumiranju imaju uvjerenja, dok su Scheier i Botvin (1997) slično pronašli za očekivano konzumiranje (vjerojatnost konzumiranja u budućnosti), no ni jedno ni drugo istraživanje ne ukazuje na utjecaj znanja o psihoaktivnim tvarima na samo konzumiranje.

Flay i Petraitis (2003) obrazlažu načine na koje prevencijske teorije mogu biti temeljem preventivnih programa te navode da su intervencijski programi usmjereni podizanju razine znanja predstavljali prvi val ulaganja u prevenciju utemeljenu na teorijama. Taj val bio je aktualan šezdesetih godina prošloga stoljeća i počivao je na pretpostavci da ako poučimo mlade o štetnosti psihoaktivnih tvari i svim rizicima koji uz njih idu, posebno onim dugoročnim, velika je vjerojatnost da će se suzdržavati od konzumiranja. lako to na prvi pogled djeluje zdravorazumski, autori navode da su takvi programi uglavnom bili neuspješni, i to iz nekoliko razloga. Prvo, nove informacije o drogama ponekad su utjecale na veće konzumiranje (Goodstadt, 1978; prema Flay i Petraitis, 2003). Drugo, dugoročne posljedice nisu primamljiv "materijal” za mozak adolescenta koji je usmjeren na kratkoročno te vrednuje događaje i svijet prije svega u tom kratkoročnom kontekstu. Treći je razlog usmjerenost tih programa na jednu determinantu uporabe psihoaktivnih tvari, što je samo po sebi dovoljno ograničenje s obzirom na kompleksnu prirodu etiologije problema u ponašanju pa tako i konzumiranja psihoaktivnih tvari. Četvrti razlog, koji navode isti autori, veže se uz usmjerenost na jednostrano prikazivanje informacija koje se odnose samo na štetnost i rizike konzumiranja, što nije u skladu s onim što čuju od vršnjaka i iz medija. Tomu treba dodati i činjenicu da jednostrane informacije o konzumiranju ne sadrže razloge zašto se ljudi uopće upuštaju u to ponašanje, što su često socijalno prihvatljivi i očekivani razlozi - zabava, opuštanje i druženje s vršnjacima. Problem često nije u razlozima, već u tome što mladi teško kritički prosuđuju i razlikuju informacije "za» $\mathrm{i}$ «protiv», što je također u skladu sa značajkama njihove razvojne dobi. Autori nadalje navode i nedostatak tih programa zbog činjenice da su univerzalni, čime pružaju nepotrebne informacije 
velikoj većini mladih iz opće populacije koji nisu u riziku ili su u vrlo niskom riziku za konzumiranje psihoaktivnih tvari dok oni koji su u povećanom riziku ne dobivaju dovoljno ciljanih intervencija (Goodstadt, 1978; prema Flay i Petraitis, 2003).

Što se samog znanja o drogama tiče, Stoelben, Krappweis, Rössler i Kirch (2000) zaključuju da mladi znanje o drogama zapravo stječu tijekom konzumiranja, a ne prije, što također daje značajan materijal za interpretaciju rezultata predstavljenih u ovom radu, posebno onih da mladi koji više znaju o psihoaktivnim tvarima, ujedno ih više i konzumiraju. To bi moglo upućivati na zaključak da su oni koji više konzumiraju ujedno i informiraniji o drogama baš zato što im je to zanimljiva tema jer je to tema i aktivnost koja ih okupira i predstavlja značajan dio njihova života, a moguće i okosnicu njihova druženja s vršnjacima te posljedično, moguće je da predstavlja važan element postizanja statusa u vršnjačkoj skupini, upravo putem informiranosti o različitim psihoaktivnim tvarima i njihovu djelovanju. Ovo potonje posebno može biti značajno ako se pogleda kroz prizmu opisa populacije s kojom je istraživanje provedeno, a to su mladi s problemima u ponašanju, kod kojih je činjenje kaznenih djela i prekršaja već postalo važan dio statusa u društvu vršnjaka u kojem se nalaze. Navedeno je i u skladu s istraživanjima roditeljskih, školskih i vršnjačkih utjecaja na uporabu psihoaktivnih tvari i delinkvenciju u adolescenciji (Garnier i Stein, 2002; Kuntsche i Delgran Jordan, 2006), a koja pokazuju da je slično ponašanje vršnjaka, i druženje s vršnjacima koji konzumiraju psihoaktivne tvari, najsnažniji prediktor konzumiranja psihoaktivnih tvari i delinkventnog ponašanja adolescenata. 
Kriminologija i socijalna integracija Vol 27 (2019) 1, 3 - 34.

Tablica 4.: Životna prevalencija konzumiranja psihoaktivnih tvari i razlike u učestalosti konzumacije s obzirom na razinu znanja o djelovanju psihoaktivnih tvari (Mann-Whitneyjev U-test)

\begin{tabular}{|c|c|c|c|c|c|c|c|c|c|c|c|}
\hline & \multirow{2}{*}{$\begin{array}{c}\text { Životna } \\
\text { prevalencija } \\
\text { konzumiranja }\end{array}$} & \multirow{2}{*}{ Ustanova } & \multicolumn{5}{|c|}{$\%$} & \multirow{2}{*}{ PR } & \multirow{2}{*}{ MWU } & \multirow{2}{*}{$\mathbf{P}$} & \multirow{2}{*}{$\mathbf{r}$} \\
\hline & & & Nikad & $1-2 x$ & $3-4 x$ & $5-10 x$ & $10 X<$ & & & & \\
\hline \multirow{2}{*}{ Nikotin } & \multirow{2}{*}{ Cigarete } & MANJE ZN. & 2,6 & 0,0 & 5,3 & 2,6 & 89,5 & 35,26 & \multirow{2}{*}{559,0} & \multirow{2}{*}{$>, 050$} & \\
\hline & & VIŠE ZN. & 3,0 & 0,0 & 0,0 & 3,0 & 93,9 & 26,85 & & & \\
\hline \multirow{6}{*}{ Alkohol } & \multirow{2}{*}{ Pivo } & MANJE ZN. & 7,9 & 10,5 & 7,9 & 2,6 & 71,1 & 32,68 & \multirow{2}{*}{501,0} & \multirow{2}{*}{$>, 050$} & \\
\hline & & VIŠE ZN. & 0,0 & 6,3 & 3,1 & 3,1 & 87,5 & 38,84 & & & \\
\hline & \multirow{2}{*}{ Vino } & MANJE ZN. & 7,9 & 15,8 & 5,3 & 7,9 & 63,2 & 31,64 & \multirow{2}{*}{461,5} & \multirow{2}{*}{$<, 050$} & \multirow{2}{*}{30} \\
\hline & & VIŠE ZN. & 0,0 & 3,0 & 6,1 & 3,0 & 87,9 & 41,02 & & & \\
\hline & \multirow{2}{*}{$\begin{array}{l}\text { Žestoka pića (npr. } \\
\text { votka, džin, viski) }\end{array}$} & MANJE ZN. & 13,2 & 13,2 & 5,3 & 10,5 & 57,9 & 31,01 & \multirow{2}{*}{437,5} & \multirow{2}{*}{$<, 010$} & \multirow{2}{*}{,32 } \\
\hline & & VIŠE ZN. & 0,0 & 3,0 & 3,0 & 9,1 & 84,8 & 41,74 & & & \\
\hline \multirow{20}{*}{$\begin{array}{l}\text { llegalne } \\
\text { psihoaktivne } \\
\text { tvari }\end{array}$} & \multirow{2}{*}{ Marihuana } & MANJE ZN. & 26,3 & 15,8 & 5,3 & 7,9 & 44,7 & 32,14 & 4805 & $>050$ & \\
\hline & & VIŠE ZN. & 18,2 & 6,1 & 0,0 & 6,1 & 69,7 & 40,44 & 400,5 & 3,050 & \\
\hline & & MANJE ZN. & 60,5 & 10,5 & 2,6 & 0,0 & 26,3 & 29,61 & & & \\
\hline & Hasis's & VIŠE ZN. & 24,2 & 12,1 & 0,0 & 9,1 & 54,5 & 43,36 & 384,0 & $<, 010$ & 35 \\
\hline & Speed/ & MANJE ZN. & 68,4 & 5,3 & 5,3 & 5,3 & 15,8 & 31,95 & 1730 & 050 & 23 \\
\hline & amfetamini & VIŠE ZN. & 45,5 & 12,1 & 6,1 & 0,0 & 36,4 & 40,67 & $4 / 3,0$ & $<.050$ & ,23 \\
\hline & Korain & MANJE ZN. & 81,6 & 10,5 & 5,3 & 0,0 & 2,6 & 30,55 & 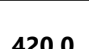 & $<010$ & 34 \\
\hline & 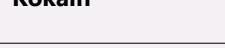 & VIŠE ZN. & 51,5 & 15,2 & 12,1 & 6,1 & 15,2 & 42,27 & $4<0,0$ & 2,010 &, 34 \\
\hline & Ecstasy (MDMA, & MANJE ZN. & 68,4 & 5,3 & 2,6 & 10,5 & 13,2 & 32,21 & & & \\
\hline & "bomboni") & VIŠE ZN. & 45,5 & 15,2 & 3,0 & 9,1 & 27,3 & 40,36 & 483,0 & $>, 050$ & \\
\hline & ISD & MANJE ZN. & 86,1 & 2,8 & 5,6 & 0,0 & 5,6 & 32,78 & 5140 & $>050$ & \\
\hline & LSD & VIŠE ZN. & 72,7 & 6,1 & 3,0 & 12,1 & 6,1 & 37,42 & 314,0 & 3,050 & \\
\hline & Heroin & MANJE ZN. & 94,6 & 2,7 & 0,0 & 0,0 & 2,7 & 34,42 & 5705 & $>050$ & \\
\hline & nerom & VIŠE ZN. & 87,9 & 9,1 & 0,0 & 0,0 & 3,0 & 36,71 & 310,3 & 3,050 & \\
\hline & Ketamin & MANJE ZN. & 91,2 & 2,9 & 2,9 & 0,0 & 2,9 & 31,38 & 4720 & $>050$ & \\
\hline & Ketamin & VIŠE ZN. & 78,1 & 6,3 & 6,3 & 0,0 & 9,4 & 35,75 & $4 / 2,0$ & 3,050 & \\
\hline & ICE & MANJE ZN. & 100,0 & 0,0 & 0,0 & 0,0 & 0,0 & 33,00 & & & \\
\hline & $\begin{array}{l}\text { (metamfetamin, } \\
\text { "meth") }\end{array}$ & VIŠE ZN. & 87,9 & 3,0 & 0,0 & 3,0 & 6,1 & 37,18 & 522,0 & $<, 050$ & ,26 \\
\hline & Metadon, Subutex, & MANJE ZN. & 73,0 & 10,8 & 0,0 & 0,0 & 16,2 & 31,88 & 765 & $>0$ & \\
\hline & Subox & VIŠE ZN. & 53,1 & 12,5 & 6,3 & 6,3 & 21,9 & 38,61 & $4 / 0,5$ & $>.050$ & \\
\hline "Legalne"/ & Lažni osvježivači & MANJE ZN. & 50,0 & 5,3 & 2,6 & 10,5 & 31,6 & 31,34 & & & \\
\hline psihoak. tvari & $\begin{array}{l}\text { prostora (npr. } \\
\text { Galaxy, Atomix) }\end{array}$ & VIŠE ZN. & 18,2 & 18,2 & 6,1 & 9,1 & 48,5 & 41,36 & 450,0 & 3,050 & \\
\hline & Tablete & MANJE ZN. & 48,6 & 5,4 & 8,1 & 13,5 & 24,3 & 32,24 & 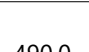 & $>050$ & \\
\hline Lijekovi i & $\begin{array}{l}\text { sedativi/hipnotici) } \\
\text { s.tili }\end{array}$ & VIŠE ZN. & 30,0 & 15,2 & 3,0 & 12,1 & 39,4 & 39,15 & 490,0 & $>, 050$ & \\
\hline inhalati & Inhalanti (ljepilo, & MANJE ZN. & 91,4 & 5,7 & 0,0 & 0,0 & 2,9 & 32,83 & & & \\
\hline & aceton, boje) & VIŠE ZN. & 81,8 & 3,0 & 9,1 & 0,0 & 6,1 & 36,27 & 519,0 & $>, 050$ & \\
\hline
\end{tabular}

Legenda: Manje zn. = manje znanja; Više zn. = više znanja; $P R=$ prosječni rang; $M W U=$ Mann-Whitneyjev U-test; $p=$ značajnost; $r=$ veličina efekta 
Neven Ricijaš, Valentina Kranželić, Lorena Leskovar: Prevalencija i učestalost konzumiranja...

Tablica 5.: Godišnja prevalencija konzumiranja psihoaktivnih tvari i razlike u učestalosti konzumacije s obzirom na razinu znanja o djelovanju psihoaktivnih tvari (Mann-Whitneyjev U-test)

\begin{tabular}{|c|c|c|c|c|c|c|c|c|c|c|c|}
\hline & \multirow{2}{*}{$\begin{array}{l}\text { Godišnja } \\
\text { prevalencija } \\
\text { konzumiranja }\end{array}$} & \multirow{2}{*}{ Ustanova } & \multicolumn{5}{|c|}{$\%$} & \multirow{2}{*}{ PR } & \multirow{2}{*}{ MWU } & \multirow[b]{2}{*}{$\mathbf{p}$} & \multirow{2}{*}{$\mathbf{r}$} \\
\hline & & & Nikad & $1-2 x$ & $3-4 x$ & $5-10 x$ & $10 X<$ & & & & \\
\hline \multirow{2}{*}{ Nikotin } & \multirow{2}{*}{ Cigarete } & MANJE ZN. & 7,9 & 2,6 & 2,6 & 2,6 & 84,2 & 34,36 & \multirow{2}{*}{564,5} & \multirow{2}{*}{$>, 050$} & \\
\hline & & VIŠE ZN. & 2,9 & 0,0 & 0,0 & 0,0 & 97,1 & 38,90 & & & \\
\hline \multirow{6}{*}{ Alkohol } & \multirow{2}{*}{ Pivo } & MANJE ZN. & 10,8 & 13,5 & 10,8 & 8,1 & 56,8 & 35,27 & \multirow{2}{*}{602,0} & \multirow{2}{*}{$>, 050$} & \\
\hline & & VIŠE ZN. & 24,2 & 3,0 & 3,0 & 6,1 & 63,6 & 35,76 & & & \\
\hline & \multirow{2}{*}{ Vino } & MANJE ZN. & 14,3 & 8,6 & 11,4 & 11,4 & 54,3 & 34,00 & \multirow{2}{*}{560,0} & \multirow{2}{*}{$>, 050$} & \\
\hline & & VIŠE ZN. & 20,6 & 11,8 & 0,0 & 0,0 & 67,6 & 36,03 & & & \\
\hline & \multirow{2}{*}{$\begin{array}{l}\text { Žestoka pića (npr. } \\
\text { votka, džin, viski) }\end{array}$} & MANJE ZN. & 21,6 & 13,5 & 10,8 & 8,1 & 45,9 & 34,27 & \multirow{2}{*}{565,0} & \multirow{2}{*}{$>, 050$} & \\
\hline & & VIŠE ZN. & 20,6 & 8,8 & 8,8 & 2,9 & 58,8 & 37,88 & & & \\
\hline \multirow{20}{*}{$\begin{array}{l}\text { llegalne } \\
\text { psihoaktivne } \\
\text { tvari }\end{array}$} & \multirow{2}{*}{ Marihuana } & MANJE ZN. & 40,5 & 10,8 & 10,8 & 5,4 & 32,4 & 32,80 & \multirow{2}{*}{510,5} & \multirow{2}{*}{$>, 050$} & \\
\hline & & VIŠE ZN. & 32,4 & 0,0 & 5,9 & 11,8 & 50,0 & 39,49 & & & \\
\hline & Wo:̌̌ & MANJE ZN. & 77,1 & 5,7 & 0,0 & 0,0 & 17,1 & 30,00 & 1300 & 5050 & 27 \\
\hline & nasis & VIŠE ZN. & 48,5 & 12,1 & 0,0 & 9,1 & 30,3 & 39,27 & $4<0,0$ & $<, 050$ &, $2 \pi$ \\
\hline & Crond & MANJE ZN. & 78,4 & 5,4 & 2,7 & 2,7 & 10,8 & 33,03 & 5100 & 7050 & \\
\hline & Speed/amretamini & VIŠE ZN. & 61,8 & 2,9 & 8,8 & 5,9 & 20,6 & 39,24 & 519,0 & 3,050 & \\
\hline & Katuin & MANJE ZN. & 86,5 & 8,1 & 2,7 & 0,0 & 2,7 & 33,04 & 5105 & 3050 & \\
\hline & KOKaln & VIŠE ZN. & 70,6 & 8,8 & 0,0 & 8,8 & 11,8 & 39,22 & 519,5 & 3,050 & \\
\hline & Ecstasy (MDMA, & MANJE ZN. & 83,8 & 2,7 & 5,4 & 0,0 & 8,1 & 31,76 & 1720 & 5050 & 27 \\
\hline & "bomboni") & VIŠE ZN. & 58,8 & 5,9 & 11,8 & 5,9 & 17,6 & 40,62 & $4 / 2,0$ & $<, 050$ & , 21 \\
\hline & ISD & MANJE ZN. & 91,9 & 5,4 & 0,0 & 0,0 & 2,7 & 33,36 & 5215 & 7050 & \\
\hline & LOD & VIŠE ZN. & 76,5 & 11,8 & 5,9 & 2,9 & 2,9 & 38,87 & מנונד & (3,050 & \\
\hline & & MANJE ZN. & 94,6 & 5,4 & 0,0 & 0,0 & 0,0 & 35,39 & & & \\
\hline & neromin s s & VIŠE ZN. & 91,2 & 5,9 & 0,0 & 2,9 & 0,0 & 36,66 & 000,3 & (3,050 & \\
\hline & Ketomin & MANJE ZN. & 97,3 & 0,0 & 0,0 & 0,0 & 2,7 & 34,49 & 5730 & 7050 & \\
\hline & Netammint s & VIŠE ZN. & 88,2 & 5,9 & 0,0 & 0,0 & 5,9 & 37,65 & J10,0 & (2,050 & \\
\hline & & MANJE ZN. & 100,0 & 0,0 & 0,0 & 0,0 & 0,0 & 34,00 & & & \\
\hline & $\begin{array}{l}\text { (metametamin, } \\
\text { "meth") }\end{array}$ & VIŠE ZN. & 90,9 & 0,0 & 0,0 & 6,1 & 3,0 & 37,18 & 553,0 & $>, 050$ & \\
\hline & Metadon, & MANJE ZN. & 78,9 & 7,9 & 0,0 & 0,0 & 13,2 & 35,09 & & & \\
\hline & Suboxone & VIŠE ZN. & 70,6 & 5,9 & 5,9 & 2,9 & 14,7 & 38,07 & 592,5 & $>, 050$ & \\
\hline „Legalne“/ & Lažni osvježivači & MANJE ZN. & 59,5 & 2,7 & 8,1 & 2,7 & 27,0 & 33,45 & 5215 & $>050$ & \\
\hline $\begin{array}{l}\text { Nove } \\
\text { psihoak. tvari }\end{array}$ & $\begin{array}{l}\text { prostora (npr. } \\
\text { Galaxy, Atomix) }\end{array}$ & VIŠE ZN. & 38,2 & 11,8 & 5,9 & 20,6 & 23,5 & 38,78 & 534,5 & $>, 050$ & \\
\hline & Tablete & MANJE ZN. & 59,5 & 10,8 & 8,1 & 2,7 & 18,9 & 34,53 & & & \\
\hline Lijekovi i & $\begin{array}{l}\text { (anksiolitil|CI/ } \\
\text { sedativi/hipnotici) }\end{array}$ & VIŠE ZN. & 52,9 & 8,8 & 8,8 & 2,9 & 26,5 & 37,60 & $b / 4,5$ & $>, 050$ & \\
\hline & Inhalanti (ljepilo, & MANJE ZN. & 97,4 & 0,0 & 0,0 & 0,0 & 2,6 & 35,97 & 6260 & $>050$ & \\
\hline & aceton, boje) & VIŠE ZN. & 94,1 & 5,9 & 0,0 & 0,0 & 0,0 & 37,09 & $0<0,0$ & & \\
\hline
\end{tabular}

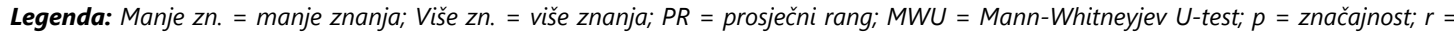
veličina efekta 


\section{Istraživačka ograničenja}

Većina znanstveno-istraživačkih izazova i ograničenja u ovoj studiji odnosi se na sve tipične izazove primijene metode samoiskaza, a koje je Ručević (2008) kvalitetno prikazala i sistematizirala u svojem radu. Prije svega to se odnosi na probleme pouzdanosti i valjanosti podataka korištenjem ove metodologije zbog problema dosjećanja, razumijevanja tvrdnji, iskrenosti sudionika, njihova potencijalnog zamora i sličnog. Da bismo u najvećoj mogućnoj mjeri nadišli navedene izazove, važno je bilo kvalitetno obučiti istraživače prilikom provedbe istraživanja, posebno zbog pristupa maloljetnicima, osiguravajući im psihološki siguran prostor, gradeći povjerenje u anonimnost i tajnost svih podataka. Istraživači su također osigurali dovoljan broj obučenih anketara koji su bili na raspolaganju maloljetnicima ako je bilo potrebno neko pitanje pojasniti ili detaljnije obrazložiti, ali i pročitati u slučaju slabije pismenosti mladih.

Jedno od istraživačkih ograničenja svakako je i prigodan uzorak sudionika iako je intencija istraživača bila osigurati populaciju mladih u navedenim ustanovama. Ovaj izazov teško je nadići iz realnih (primjerice, bjegovi ili opravdana izbivanja maloljetnika iz ustanove) i etičkih razloga (pravo maloljetnika na odbijanje sudjelovanja u istraživanju). Međutim, s obzirom na to da se radi o nesistemskim čimbenicima selekcije sudionika, dobivene rezultate nije moguće generalizirati na sve maloljetnike smještene u sustavu socijalne skrbi/pravosuđa, kao što valja naglasiti da su u istraživanju sudjelovali samo mladići, što znači da rezultate nije moguće generalizirati niti na djevojke $s$ problemima u ponašanju.

Podjelom mladih na one s više znanja i manje znanja dobiveni su određeni pokazatelji testiranih razlika, međutim istraživačka ograničenja odnose se na tendenciju grupiranja rezultata oko središnjih vrijednosti. Veći uzorci (>100 sudionika) omogućili bi kategorizaciju prema kvartilima, čime bi se mogao dobiti uvid $u$ eventualne razlike s obzirom na ekstreme, odnosno testirati razlike između prvog i četvrtog kvartila s obzirom na razinu znanja.

S obzirom na to da su ovim istraživanjem, s prevalencijskog aspekta, dobiveni detaljni podatci o konzumiranju različitih psihoaktivnih tvari teško dostupne populacije, odnosno populacije koja često nije uključena u istraživanjima opće populacije mladih, buduća istraživanja, temeljem navedenih frekventnih sredstava, mogu veći naglasak staviti na istraživanje korelata u kontekstu drugih sociodemografskih i psiholoških varijabli (primjerice, dob i kontekst prve konzumacije, motivacija, osobine ličnosti, obiteljski hereditet i slično), a koje bi dodatno rasvijetlile mehanizme razvoja problema u ponašanju.

\section{Zaključak}

Dvije važne poruke proizlaze iz ovog istraživanja. Jedna se odnosi na podatak o visokoj prevalenciji i učestalosti uporabe psihoaktivnih tvari među mladima s problemima u ponašanju smještenima u ustanove socijalne skrbi i pravosuđa u Hrvatskoj, a druga na podatak da je veće znanje o psihoaktivnim tvarima povezano i s većim konzumiranjem istih. Obje poruke donose vrijedne implikacije za planiranje i provođenje cijelog spektra intervencija u području uporabe psihoaktivnih tvari kod mladih s problemima u ponašanju. 
Neven Ricijaš, Valentina Kranželić, Lorena Leskovar: Prevalencija i učestalost konzumiranja...

Preventivne intervencije u području konzumiranja psihoaktivnih tvari, s obzirom na razinu prevencije (univerzalna - za opću populaciju, selektivna - populacije u povišenom riziku i indicirana - populacije s već izrađenim ponašanjem konzumiranja, no ne i ovisnosti koja bi zahtijevala tretmanske intervencije), mogu imati različite ciljeve, od kojih su neki (Cuijpers, 2003): (1) povećanje znanja o psihoaktivnim tvarima kod adolescenata; (2) smanjivanje uporabe psihoaktivnih tvari; (3) odgoda prve uporabe psihoaktivnih tvari; (4) smanjivanje uporabe psihoaktivnih tvari, te (5) minimaliziranje štete nastale uporabom psihoaktivnih tvari.

Iz istraživanja učinkovitosti preventivnih programa u područjwu konzumiranja psihoaktivnih tvari jasno je da informacije same po sebi nisu dostatna komponenta programa (Toumbourou i sur., 2007). Poznata je, i u zadnjih 15 - 20 godina i znanstveno dokazana činjenica da programi temeljeni na samostalnom pružanju informacija mogu imati i štetne učinke, posebno na povećanu uporabu psihoaktivnih tvari (Werch i Owen, 2002). S obzirom na to da informacije ipak jesu i trebaju biti važan sastavni dio sveobuhvatnih intervencija, ponajprije zato jer omogućavaju razvoj kritičkog promišljanja o (ne)zdravim ponašanjima i posljedicama izbora ponašanja, važno ih je ugraditi na odgovarajući način. Najčešće se to radi u kombinaciji s drugim komponentama programa te im se pristupa poticanjem kritičkog razmišljanja (Faggiano i suradnici, 2005). Tako Lemstra i suradnici (2010) navode da su programi prevencije konzumiranja alkohola i marihuane namijenjeni adolescentima u dobi 10 - 15 godina koji su, uz informacije, sadržavali i razvoj vještina odolijevanja pritisku, vještina upravljanja sobom te trening socijalnih vještina, dugoročno bili najučinkovitiji. Autori temeljem toga zaključuju da, iako značajno zahtjevnije za pripremu i izvedbu, sveobuhvatne višefaktorske intervencije imaju veću vjerojatnost dugoročnog utjecaja na promjenu ponašanja. Neki autori napominju da je za konačne i praktično vrijedne zaključke važno provoditi istraživanja učinkovitosti programa na populacijama različite razine rizika. Naime, iz dosadašnjih istraživanja jasno je da nešto što se pokazuje učinkovitim na univerzalnoj razini (i u općoj populaciji), ne podrazumijeva nužno učinkovitost s populacijama u povišenom riziku, kao ni s onima s već izraženim problemima povezanim s konzumiranjem psihoaktivnih tvari (Elliot i sur., 2005). Isto vrijedi i za mlade koji konzumiraju psihoaktivna sredstva te imaju i druge probleme mentalnog zdravlja (Salvo i suradnici, 2012). Jedna analiza preventivnih programa s populacijama u riziku (Roe i Becker, 2005) pokazuje da su se najučinkovitijima pokazali programi temeljeni na razvoju socijalnih vještina (barem kao kratkoročni učinci) te oni intenzivni višekomponentni programi u zajednicama, a dob od 11 do 13 godina pokazala se najadekvatnijom za uključivanje u preventivne intervencije s populacijama u riziku. Pregledom literature o učinkovitosti univerzalnih, selektivnih i indiciranih preventivnih programa, Cuijpers (2003) zaključuje da nema dovoljno dokaza da su selektivni i indicirani programi u školskom okruženju učinkoviti te upućuje na daljnja istraživanja značajki populacije u povišenom riziku. Isti autor navodi da je većina istraživanja usmjerena učincima programa na povećanje znanja i smanjivanje uporabe, ali nedostaje istraživanja kojima bi se pronalazili dokazi da je moguće smanjiti broj novih slučajeva problematične uporabe psihoaktivnih tvari. Faggiano i suradnici (2005) temeljem sustavna pregleda literature zaključuju da su najučinkovitiji programi u školskom okruženju oni koji se temelje na razvoju vještina, a programi temeljeni na znanju i emocionalnoj edukaciji još uvijek trebaju dodatna istraživanja i potvrdu učinkovitosti.

Temeljem sveobuhvatna pregleda literature u području Cuijpers (2003) navodi kriterije kvalitete znanstveno-utemeljenih programa prevencije konzumiranja psihoaktivnih sredstava, a odnose se 
na model socijalnih utjecaja (utjecaj vršnjaka, medija, roditelja i drugih) kao najbolji temelj za sadržaj programa prema dostupnim znanjima, zatim usmjerenost normama, predanosti ne-uporabi i namjeri ne-uporabe, nužnosti dodavanja intervencija u zajednici koje jačaju učinke programa, te uključivanje programa razvoja socijalnih vještina koji također mogu jačati učinak programa. 
Neven Ricijaš, Valentina Kranželić, Lorena Leskovar: Prevalencija i učestalost konzumiranja...

\section{Literatura}

Afolabi, M.O., Ayilara, A.E., Akinemi, O.A., Ola-Olarun, N. (2012). Survey of drug use among young people in Ife, Nigeria. African Journal of Drug and Alcohol Studies, 11 (2), 87-94.

Američka psihijatrijska udruga (2014). DSM-5. Jastrebarsko: Naklada Slap.

Andrews, J.A., Tildesley, E., Hops, H., Li, F. (2002). The Influence of Peers on Young Adult Substance Use. Health Psychology, 21(4), 349-357.

Barkin, S.L., Smith, K.S., DuRant, R.H. (2002). Social skills and attitudes associated with substance use behaviors among young adolescents. Journal of Adolescent Health, 30 (6), 448-454. doi: 10.1016/s1054-139x(01)00405-0

Barnea, Z., Teichman, M., Rahav, G. (1992). Personality, cognitive, and interpersonal factors in adolescent substance use: A longitudinal test of an integrative model. Journal of Youth and Adolescence, 21 (2), 187-201.

Bava, S., Tapert, S.F. (2010). Adolescent Brain Development and the Risk of Alcohol and Other Drug Problems. Neuropsychology Review, 20 (4), 398-413.

Blue Moon Research and Planning (2000). Illicit Drugs: Research to aid in the development of strategies to target youth and young people. Commonwealth Department of Health and Aged Care: Canberra.

Brlas, S. (2011). Rječnik ovisnosti. Virovitica: Zavod za javno zdravstvo "Sveti Rok" Virovitičkopodravske županije.

Bryan, A., Moran, R., Farrell, E. , O'Brien, M. (2000). Drug- Related Knowledge Attitudes and Beliefs in Ireland. Report of a Nation-Wide Survey. Dublin: The Health Research Board.

Centre for Behavioural Research (2012). Australian secondary school students' use of tobacco, alcohol, and over-the-counter and illicit substances in 2011. Cancer: The Cancer Council Victoria.

Chambers, R.A., Taylor, J.R., Potenza, M.N. (2003). Developmental Neurocircuitry of Motivation in Adolescence: A Critical Period of Addiction Vulnerability. American Journal of Psychiatry, 160 (6), 1041-1052. doi: https://dx.doi.org/10.1176\%2Fappi.ajp.160.6.1041

Chassin, L. (2008). Juvenile Justice and Substance Use. The Future of Children, 18 (2), 165-183.

Chassin, L., Ritter, J., Trim, R.S., King, K.M. (2003). Adolescent Substance Use Disorders. U: Mash, E.J., Barkley, R.A. (ur.), Child Psychopathology (pp. 199-230). New York, NY, US: Guilford Press.

Cleveland, M.J., Feinberg, M.E., Bontempo, D.E., Greenberg, M.T. (2008). The Role of Risk and Protective factors in Substance Use Across Adolescence. Journal of Adolescent Health, 43(2), 157-164.

Concise International Chemical Assessment Documents (2015). Report on Drug Use in the Americas. Washington D.C.: Organization of American States.

Cosci, F., Zaga, V., Bertoli, G., Campiotti, A. (2013). Significant Others, Knowledge, and Belief on Smoking as Factors Associated with Tobacco Use in Italian Adolescents. ISRN Addiction, (968505), 1-7. doi: $h$ ttp://dx.doi.org/10.1155/2013/968505

Cuijpers, P. (2003). Three decades of drug prevention research. Drugs: Education, Prevention And Policy, 10 (1), 7-20. doi: https://doi.org/10.1080/0968763021000018900 
Elek, E., Miller-Day, M., Hecht, M.L. (2006). Influences of Personal, Injunctive, and Descriptive Norms on Early Adolescent Substance Use. Journal of Drug Issues, 36 (1), 147-172.

Elliott, L., Orr, L., Watson, L., Jackson, A. (2005). Secondary prevention interventions for young drug users: A systematic review of the evidence. Adolescence, 40 (157), 1-22.

Ennett, S.T., Bauman, K.E., Hussong, A.M., Faris, R., Foshee, V.A., Cai, L., DuRant, R.H. (2016). The Peer Context of Adolescent Substance Use: Findings from Social Network Analysis. Journal of Research on Adolescence, 16 (2), 159-186. doi: 10.1007/s11121-008-0087-8

Faggiano, F., Vigna-Taglianti, F.D., Versino, E., Zambon, A., Borraccino, A., Lemma, P. (2005). School-based prevention for illicit drugs' use (Review). The Cohrane Collaboration. Wiley\&Sons.

Flay, B.R., Petraitis, J. (2003). Bridging the gap between substance use prevention theory and practice. U Sloboda, A., Bukoski, W.J. (ur.), Handbook of Drug Abuse Prevention: Theory, science, and practice (289-305). New York: Kluwer Academic/Plenum Publishers.

Ganley, B.J., Rosario, D.I. (2013). The smoking attitudes, knowledge, intent, and behaviours of adolescents and young adults: Implications for nursing practice. Journal of Nursing Education and Practice, 3 (1), 40-50. doi: https://doi.org/10.5430/jnep.v3n $1 p 40$

Garnier, H.E., Stein, J.A. (2002). An 18-year model of family and peer effects on adolescent drug use and delinquency. Journal of youth and adolescence, 31(1), 45-56.

Miller, E. O. (2007). Why do Danish teenagers drink so much? (Book Review). Nordic Studies on alcohol and drugs, 24 (2), 221-226.

Haddad, L., Shotar, A., Umlauf, M., Al Zyoud, S. (2010). Knowledge, Attitudes, and Beliefs on Substance Abuse Among High School Students in Jordan. Journal of Transcultural Nursing, 21 (2), 143-150.

Hammersley, R., Marsland, L., Reid, M. (2003). Substance abuse by young offenders. London: Home Office Research Development and Statistics Directorate.

Han, M.Y., Chen, W.Q., Chen, X. (2011). Do smoking Knowledge, Attitudes and Behaviours Change with Years of Schooling? A Comparison of Medical with Non- Medical Students in China. Journal of Community Health, 36 (6), 966-974.

Health Canada (2013). The Youth Smoking Survey. Preuzeto s: http://healthycanadians.gc.ca/publications/healthy-living-vie-saine/youth-smoking-survey-2013-enquete-jeunes-tabagisme/ index-eng.php. (5.1.2019.)

Horgan, J. (2013). Drug and alcohol misuse among young offenders on supervision in Ireland. Dublin: Probation Services.

Institute for Mental Health Policy Research (2015). Ontario Student Drug Use and Health Survey: Drug Use among Ontario students. Canada: Centre for Addiction and Mental Health.

Jukić, V. (2006). Ovisnosti o drogama. U Hotujac, LJ. (ur.), Psihijatrija (129-141). Zagreb: Medicinska naklada.

Kenny, D.T., Nelson, P.K. (2008). Young offenders on community orders: Health, Welfare, And Criminogenic Needs. Sydney: Sydney University Press.

King, K.M., Chassin, L. (2007). A Prospective Study of the Effects of Age of Initiation of Alcohol and Drug Use on Young Adult Substance Dependence. Journal of Studies on Alcohol and Drugs, 68 (2), 256-265.

Klatt, T. (2016). Predictors of Drug Use in Young Offender Institution. Germany: Criminological Research Institute of Lowe Saxony Germany. Preuzeto s: https://www.criminologysymposium.com/ 
Neven Ricijaš, Valentina Kranželić, Lorena Leskovar: Prevalencija i učestalost konzumiranja...

download/18.62fc8fb415c2ea106932ae84/1499781904868/WED11+Thimna+Klatt. pdf (10.1.2019.).

Klink, K., Lin, S., Elkin, Z., Strigenz, D., Liu, S. (2011) Smoking Cessation Knowledge, Attitudes, and Practice Among Community Health Providers in China. Family Medicine, 43 (3), 198-200.

Kosterman, R., Hawkins, D.J., Guo, J., Catalano, R.F., Abbott, R.D. (2000). The Dynamic of Alcohol and Marijuana Initiation: Patterns and Predictors of First Use in Adolescence. American Journal of Public Health, 90 (3), 360-366.

Krnić, D., Čorak, D., Modrić, I. (2013). Droga i mladi. Zagreb: Agencija za komercijalnu djelatnost d.o.o.

Kuntsche, E., Delgran Jordan, M. (2006). Adolescent alcohol and cannabis use in relation to peer and school factors: Results of multilevel analyses. Drug and alcohol dependence, 84 (2), 167-174.

Lader, D., Singleton, N., Meltzer, H. (2003). Psychiatric morbidity among young offenders in England i Wales. London: National Statistics.

Lebeau-Craven, M.P.H., Stein, L., Barnett, N., Colby, S.M., Smith, J.L., Canto, A.L. (2003). Prevalence of Alcohol and Drug Use in Adolescent Training Facility. Substance Use and Misuse, 38 (7), 825-834.

Lemstra, M., Bennett, N., Nannapaneni, U., Neudorf, C., Warren, L., Kershaw, T., Scott, C. (2010). A systematic review of school-based marijuana and alcohol prevention programs targeting adolescents aged 10-15. Addiction research and theory, 18 (1), 84-96.

Li, S., Huang, H., Xu, G., Cai, Y., Huang, F., Ye, X. (2013). Substance use, risky sexual behaviours, and their associations in a Chinese sample of senior high school students. BMC Public Health, 13 (1), 295- 305. doi: 10.1186/1471-2458-13-295

Lin, Y. S., Wu, D. M., Lai H. R., Shi, Z. P., Chu, N. F. (2010). Influence of knowledge and attitudes on smoking habits among young military conscripts in Taiwan. Journal of the Chinese Medical Association, 73 (8), 411-418. doi: https://doi.org/10.1016/S1726-4901(10)70089-7

Mauricio, M.A., Little, M., Chassin, L., Knight, G.P. Piquero, A.R., Losoya, S.H., Vargas-Chanes, D. (2009). Juvenile Offenders Alcohol and Marijuana Trajectories: Risk and Protective Factor Effects in Context of Time in Supervised Facility. Youth Adolescence, 38 (1), 440-453.

Monti, P.A., Miranda, R., Nixon, K.J., Sher, K.J., Swartzwelder, S., Tapoet, S.F., White, A., Crews, F.T. (2005). Adolescence: Booze, Brains and Behaviour. Alcoholism: Clinical and Experimental Research, 29 (2), 207-220.

Mulvey, E.P., Schubert, C.A., Chassin, L. (2010). Substance Use and Delinquent Behaviour Among Serious Adolescent Offenders. USA: U.S. Department of Justice. Substance Use and Delinquent.

National Institute on Drug Abuse (2014). Commonly Used Terms in Addiction. Preuzeto s: https:// www.drugabuse.gov/publications/media-guide/glossary (10.1.2019.).

National Institute on Drug Abuse (2016). Substance use disorders extremely common among

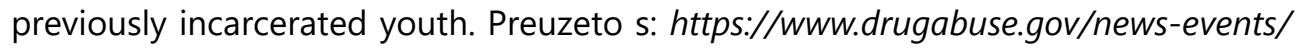
news-releases/2016/03/substance-use-disorders-extremely-common-among-previously-incarcerated-youth. (10.1.2019.)

Nobile, C.G.A., Anfosso, R., Pavia, M., Angelillo, I.F. (2000). Cigarette smoking: Knowledge, attitudes and behavior in an adult population in Italy. Public Health, 114 (5), 348-352. 
Ogunwale, A. (2011). Cannabis Use and Crime Among Young Offenders in a Correctional Center in South-Western Nigeria. Neuropsychoatroe de l'Enfance et de l'Adolescence, 60 (5), S280.

doi: https://doi.org/10.1016/j.neurenf.2012.04.764

Sloboda, Z., Petras, H. (2014). Defining prevention science. New York, NY: Springer.

Petz, B. (2005). Psihologijski rječnik. Jastrebarsko: Naklada Slap.

Prichard, J., Payne, J. (2005). Key findings from the Drug Use Careers of Juvenile Offenders study. Canberra: Australian Government.

Putninš, A. L. (2001). Substance use by south Australian young offenders. Adelaide: Office of Crime Statistics.

Redmond, S., Devaney, E. (2010). Drug and Alcohol- Related Knowledge, Attitudes and Behavior. Ireland: Youth Studies Ireland, 5 (1), 34- 48.

Roe, S., Becker, J. (2005). Drug prevention with vulnerable young people: A review. Drugs: Education, Prevention, And Policy, 12 (2), 85-99.

Ručević, S. (2008). Metodološki postupci i izazovi primjene samoiskaza i longitudinalnih nacrta u istraživanjima razvoja delinkventnog ponašanja. Ljetopis socijalnog rada, 15 (3), 421-443.

Rutten, F. LJ., Augustson, E.M., Moser, R.P., Beckjord, E.B., Hesse, B.W. (2008). Smoking knowledge and behavior in the United States: sociodemographic, smoking status, and geographic patterns. Nicotine and Tobacco Research, 10 (10), 1559-1570. doi: 10.1080/14622200802325873

Sakoman, S. (2009). Školski programi prevencije ovisnosti. Zagreb: Agencija za odgoj i obrazovanje.

Salvo, N., Bennett, K., Cheung, A., Chen, Y., Rice, M., Rush, B., Bullock, H., Bowlby, A. (2012). Prevention of substance use in children/adolescents with mental disorders: A systematic review. Journal of Canadian Academy of Child and Adolescent Psychiatry, 21 (4), 245-252.

Santos, A., Carvahlo, J., Campanha, R., Ribiero, I., Matos, C., Nogueir, F. (2016). Comparing behavior, attitude and knowledge about smoking cessation between smoking and non-smoking

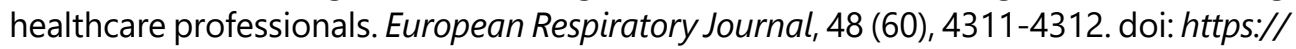
doi.org/10.1183/13993003.congress-2016.PA4311

Scheier, L.M., Botvin, G.J. (1997). Expectancies as mediators of the effects of social influences and alcohol knowledge on adolescent alcohol use: A prospective analysis. Psychology of addictive behaviors, 11 (1), 48-64.

Sittner Hartshorn, K.J., Whitbeck, L. B., Prentice, P. (2012). Substance use disorders, Comorbidity, and Arrest Among Indigenous Adolescents. Crime and Delinquency, 61 (10), 1311-1332. doi: https://doi.org/10.1177/0011128712466372

Spear, L.P. (2000). Neurobehavioral Changes in Adolescence. Current Directions in Psychological Science, 9 (4), 111-114.

Steinberg, L., Sheffield Morris, A. (2001). Adolescent development. Annual Review of Psychology, 52 (1), 83-110.

Steinberg, L. (2007). Risk Taking in Adolescence: New Perspectives from Brain and Behavioural Sciences. Current Directions in Psychological Science, 16 (2), 55 - 59.

Steketee, M., Jonkman, H., Berten, H., Vettenburg, N. (2013). Alcohol use Among Adolescents in Europe. Utrecht: Verwey- Jonker Instituut. 
Neven Ricijaš, Valentina Kranželić, Lorena Leskovar: Prevalencija i učestalost konzumiranja...

Stoelben, S., Krappweis, J., Rössler, G., Kirch, W. (2000). Adolescents drug use and drug knowledge. European journal of pediatrics, 159 (8), 608-614.

Stone, A.L., Becker, L.G., Huber, A.M., Catalano, R.F. (2012). Review of risk and protective factors of substance use and problem use in emerging adulthood. Addictive behaviors, 37 (7), 747-775. doi: 10.1016/j.addbeh.2012.02.014

Sutherland, I., Shepherd, J.P. (2001). Social dimension of adolescent substance use. Addiction, 96 (3), 445-458.

The European Monitoring Centre for Drugs and Drug Addiction (2016). Europsko izvješće o drogama: trendovi i razvoj. Luksemburg: Ured za publikacije Europske unije.

The European School Survey Project on Alcohol and Other Drugs (2007). Drug use and related problems among very young people (under 15 year). Luxembourg: Office for Official Publications of the European Communities.

The European School Survey Project on Alcohol and Other Drugs (2012). Substance Use Among Students in 36 European Countries. Stockholm: CAN.

The European School Survey Project on Alcohol and Other Drugs (2016). Results from the European School Survey Project on Alcohol and Other Drugs. Luxembourg: Publications Office of the European Union.

The Gallup Organization (2011). Youth attitudes on drugs. Hungary: European Commission.

The South African Medical Research Council (2013). Substance use, risk behaviour and mental health among grade 8-10 learners in school in the Western Cape Province 2011. Tygerberg: South African Medical Research Council.

The Substance Abuse and Mental Health Services Administration (2014). Behavioural Health Trends in the United States: Results from 2014 National Survey on Drug Use and Health. USA: U.S. Department of Health and Human Services.

Toumbourou, J.W., Stockwell, T., Neighbors, C., Marlatt, G.A., Sturge, J., Rehm, J. (2007). Interventions to reduce harm associated with adolescent substance use. The Lancet, 369 (9570), 1391-1401.

Virno, M. (1979). Le tossicodipendenze da oppiacei. Manuale teorico-pratico di diagnosie terapia. Firenza: Noccioli.

Volkow, N.D., Koob, G.F., McLellan, A.T. (2016). Neurobiologic Advances from the Brain Disease Model of Addiction. The New England Journal of Medicine, 374 (4), 363-371.

doi: 10.1056/NEJMra1511480

Ward, M., Vaughn, T., Uden- Holman, T., Doebbeling, B.N., Clarke, W.R., Woolson, R.F. (2002). Physician knowledge attitudes and practices regarding a widely implemented guideline. Journal of Evaluation in Clinical Practice, 8 (2), 155-162.

Wen, X., Chen, W., Qian, Z., Muscat, J.E., Lu, C., Ling, W. (2008) Differences in students smokingrelated knowledge, attitudes, and behaviours among public, factory, and private secondary schools in Guangzhou, China. The Journal of School Health, 78 (1), 46-53. doi: 10.1111/j.1746-1561.2007.00265.x.

Werch, C.E., Owen, D.M. (2002). latrogenic effects of alcohol and drug prevention programs. Journal of Studies on Alcohol, 63 (5), 581-590. 
World Health Organisation (2002). The South Africa GYTS. Preuzeto s: www.afro.who.int/index. php\%3Foption\%3Dcom_docman\%26task\%3Ddoc_download\%26gid\%3D1846+\&$c d=3 \& h l=h r \& c t=c \ln k \& g l=h r(5.1 .2019$.)

World Health Organisation (2003). Global Initiative on Primary Prevention of Substance Abuse. Substance abuse in Southeast Asia: knowledge, attitudes, practices and opportunities for intervention. Switzerland: UNDCP.

World Health Organisation (2016). Psychoactive substances. Preuzeto s: http://www.who.int/substance_abuse/terminology/psychoactive_substances/en/. (1.8.2016.)

Wibberley, C. (1997). Young peopless feelings about drugs. Drugs: Education, Prevention and Policy, 4 (1), 65-78.

Youth Justice Board (2004). Substance misuse and Juvenile Offenders. London: Galahad SMS Ltd.

Xu, X., Liu, L., Sharma, M., Zhau, Y. (2015). Smoking-related Knowledge, Attitudes, Behaviours, Smoking Cessation Idea and Education Level among Young Adult Male Smokers in Chogqing, China. International Journal of Environmental Research and Public Health, 12 (2), 2135-2149. doi: 10.3390/ijerph120202135 


\section{Prilog 1.}

Tablični pregled istraživanja prevalencije konzumacije psihoaktivnih tvari opće populacije mladih/ adolescenata (Afolabi, Ayilara, Akinemi, Ola-Olarun, 2012; Centre for behavioral research, 2012; ESPAD, 2007, 2012, 2016; Health Canada, 2013; Institute for Mental Health Policy Research, 2015; Li i suradnici, 2013; SAMHSA, 2014; SAMRC, 2013; Steketee i sur., 2013; WHO, 2002, 2003; The Gallup Organization, 2011)

\begin{tabular}{|c|c|c|c|c|c|}
\hline Autori & Zemlja & Uzorak & $\begin{array}{l}\text { Karakteristike } \\
\text { uzorka }\end{array}$ & Psihoaktivne tvari & Postotak \\
\hline \multirow{2}{*}{$\begin{array}{l}\text { Gallup } \\
\text { Organization, } \\
2011\end{array}$} & \multirow[t]{2}{*}{$\begin{array}{l}27 \text { europskih } \\
\text { zemlja }\end{array}$} & \multirow[t]{2}{*}{12000} & \multirow{2}{*}{$\begin{array}{l}\text { Slučajni uzorak } \\
\text { mladih u dobi od } \\
15 \text { do } 24\end{array}$} & $\begin{array}{l}\text { Ilegalne psihoaktivne tvari } \\
\text { tipa kanabis }\end{array}$ & $\begin{array}{l}12 \% \text { (životna prevalencija) } \\
8 \% \text { (godišnja prevalencija) } \\
6 \% \text { mjesečna prevalencija) }\end{array}$ \\
\hline & & & & Legalne psihoaktivne tvari & $5 \%$ (životna prevalencija) \\
\hline \multirow{3}{*}{$\begin{array}{l}\text { Steketee i sur., } \\
2013\end{array}$} & \multirow{3}{*}{$\begin{array}{l}30 \text { europskih } \\
\text { zemlja }\end{array}$} & \multirow{3}{*}{67000} & \multirow{3}{*}{$\begin{array}{l}\text { Učenici } 7 \text { i } 9 \\
\text { razreda } \\
\text { Mdob }=13,95\end{array}$} & Alkohol & $\begin{array}{l}\text { 60,6\% (životna prevalencija) } \\
27,7 \% \text { (mjesečna prevalencija) }\end{array}$ \\
\hline & & & & $\begin{array}{l}\text { llegalne psihoaktivne tvari } \\
\text { tipa kanabis }\end{array}$ & $\begin{array}{l}\text { 9,7\% (životna prevalencija) } \\
4 \% \text { (mjesečna prevalencija) }\end{array}$ \\
\hline & & & & $\begin{array}{l}\text { llegalne psihoaktivne tvari } \\
\text { tipa heroin, kokain, ecstasy }\end{array}$ & $\begin{array}{c}\text { 2\% (životna prevalencija) } \\
0,8 \% \text { (mjesečna prevalencija) }\end{array}$ \\
\hline \multirow{4}{*}{ ESPAD, 2007} & \multirow{4}{*}{$\begin{array}{l}12 \text { europskih } \\
\text { zemlja }\end{array}$} & \multirow{4}{*}{-} & \multirow{4}{*}{$\begin{array}{l}\text { Osobe mlađe od } \\
15 \text { godina }\end{array}$} & Cigarete & $7-14 \%$ (dnevna uporaba) \\
\hline & & & & Alkohol & $\begin{array}{c}\text { 33-36\% (Danska, Estonija, UK, Finska } \\
\text { (životna prevalencija) }\end{array}$ \\
\hline & & & & $\begin{array}{l}\text { Ilegalne psihoaktivne tvari } \\
\text { tipa kanabis }\end{array}$ & $0-8 \%$ \\
\hline & & & & Inhalanti* & 13\% UK* (životna prevalencija) \\
\hline \multirow{3}{*}{ ESPAD, 2012} & \multirow{3}{*}{$\begin{array}{l}36 \text { europskih } \\
\text { zemalja }\end{array}$} & \multirow{3}{*}{103076} & \multirow{3}{*}{$\begin{array}{l}\text { Nacionalni } \\
\text { reprezentativni } \\
\text { uzorak učenika } \\
\text { Mdob=15,8 } \\
\text { godina }\end{array}$} & Cigarete & $\begin{array}{l}54 \% \text { (životna prevalencija) } \\
28 \% \text { (mjesečna prevalencija) }\end{array}$ \\
\hline & & & & Alkohol & $\begin{array}{l}\text { 87\% (životna prevalencija) } \\
79 \% \text { (godišnja prevalencija) } \\
57 \% \text { (mjesečna prevalencija) }\end{array}$ \\
\hline & & & & llegalne psihoaktivne tvari & $18 \%$ (životna prevalencija)* $^{*}$ \\
\hline \multirow{4}{*}{ ESPAD, 2016} & \multirow{4}{*}{$\begin{array}{l}35 \text { europskih } \\
\text { zemalja }\end{array}$} & \multirow{4}{*}{96043} & \multirow{4}{*}{$\begin{array}{l}\text { Nacionalni } \\
\text { reprezentativni } \\
\text { uzorak učenika } \\
\text { u dobi od } 16 \\
\text { godina }\end{array}$} & Cigarete & $\begin{array}{c}46 \% \text { (životna prevalencija) } \\
21 \% \text { (mjesečna prevalencija) }\end{array}$ \\
\hline & & & & Alkohol & $\begin{array}{c}80 \% \text { (životna prevalencija) } \\
48 \% \text { (mjesečna prevalencija) } \\
13 \% \text { intoksicirano u posljednjih } \\
\text { mjesec dana }\end{array}$ \\
\hline & & & & $\begin{array}{l}\text { llegalne psihoaktivne tvari } \\
\text { Kanabis }\end{array}$ & $\begin{array}{l}18 \% \text { (Životna prevalencija) } \\
16 \% \text { (Životna prevalencija) }\end{array}$ \\
\hline & & & & Nove psihoaktivne tvari & 4\% (životna prevalencija) \\
\hline \multirow{3}{*}{$\begin{array}{l}\text { SAMHSA, } \\
2014\end{array}$} & \multirow{3}{*}{$\begin{array}{l}50 \text { američkih } \\
\text { zemalja i } \\
\text { Kolumbija }\end{array}$} & \multirow{3}{*}{17046} & \multirow{3}{*}{$\begin{array}{l}\text { Nacionalni } \\
\text { reprezentativni } \\
\text { uzorak mladih od } \\
12 \text { do } 17 \text { godina* }\end{array}$} & Cigarete & $\begin{array}{c}\text { 4,9\% (mjesečna prevalencija) } \\
24,1 \% \text { (svakodnevnih konzumenata) }\end{array}$ \\
\hline & & & & Alkohol & $\begin{array}{l}11,5 \% \text { (mjesečna prevalencija) } \\
6,1 \% \text { binge drinking (mjesečna } \\
\text { prevalencija) }\end{array}$ \\
\hline & & & & Ilegalne psihoaktivne tvari & 9,4\% (mjesečna prevalencija) \\
\hline \multirow{5}{*}{$\begin{array}{l}\text { Health } \\
\text { Canada, } 2013\end{array}$} & \multirow{5}{*}{ Kanada } & \multirow{5}{*}{47203} & \multirow{5}{*}{$\begin{array}{l}\text { Nacionalni } \\
\text { reprezentativni } \\
\text { uzorak mladih od } \\
6 \text { do } 12 \text { razreda }\end{array}$} & Cigarete & $\begin{array}{l}\text { 13\% (životna prevalencija) } \\
4 \% \text { (mjesečna prevalencija) }\end{array}$ \\
\hline & & & & Alkohol & $\begin{array}{l}41 \% \text { (mjesečna prevalencija) } \\
29 \% \text { opijanje (godišnja prevalencija) }\end{array}$ \\
\hline & & & & $\begin{array}{l}\text { Marihuana } \\
\text { Ecstasy }\end{array}$ & $\begin{array}{l}\text { 19\% (godišnja prevalencija) } \\
3 \% \text { (godišnja prevalencija) }\end{array}$ \\
\hline & & & & $\begin{array}{c}\text { Salvia } \\
\text { Divinorum* }\end{array}$ & 2\% (godišnja prevalencija) \\
\hline & & & & $\begin{array}{l}\text { Nove psihoaktivne tvari } \\
{ }^{\star}(B Z P, T F M P P, \text { katinoni) }\end{array}$ & $\begin{array}{l}\text { 1\% za svaku od navedenih tvari } \\
\text { (godišnja prevalencija) }\end{array}$ \\
\hline
\end{tabular}


Kriminologija i socijalna integracija Vol 27 (2019) 1, 3 - 34.

\begin{tabular}{|c|c|c|c|c|c|}
\hline Autori & Zemlja & Uzorak & $\begin{array}{l}\text { Karakteristike } \\
\text { uzorka }\end{array}$ & Psihoaktivne tvari & Postotak \\
\hline \multirow{4}{*}{$\begin{array}{l}\text { Institute for } \\
\text { mental police } \\
\text { research, } 2015\end{array}$} & \multirow{4}{*}{$\begin{array}{l}\text { Kanada, } \\
\text { Ontario }\end{array}$} & \multirow{4}{*}{10426} & \multirow{4}{*}{$\begin{array}{l}\text { Stratificirani } \\
\text { cluster sample } \\
\text { uzorak mladih od } \\
7 \text { do } 12 \text { razreda }\end{array}$} & Cigarete & $\begin{array}{l}\text { 19,1\% (životna prevalencija) } \\
8,6 \% \text { (godišnja prevalencija) }\end{array}$ \\
\hline & & & & Alkohol & $\begin{array}{c}\text { 67,9\% (životna prevalencija) } \\
45,8 \% \text { (godišnja prevalencija) } \\
17,6 \% \text { opijanje (mjesečna } \\
\text { prevalencija) }\end{array}$ \\
\hline & & & & Kanabis & $\begin{array}{l}23,9 \% \text { (životna prevalencija) } \\
21,3 \% \text { (godišnja prevalencija) }\end{array}$ \\
\hline & & & & $\begin{array}{l}\text { Sintetski kanabinoidi } \\
\text { Ecstasy } \\
\text { Psilocibin ili Meskalin } \\
\text { Kokain }\end{array}$ & $\begin{array}{l}\text { 1,3\% (godišnja prevalencija) } \\
5,4 \% \text { (godišnja prevalencija) } \\
3,2 \% \text { (godišnja prevalencija) } \\
2,5 \% \text { (godišnja prevalencija) }\end{array}$ \\
\hline \multirow{3}{*}{$\begin{array}{l}\text { Centre for } \\
\text { behavioral } \\
\text { research, } 2012\end{array}$} & \multirow{3}{*}{ Australija } & \multirow{3}{*}{24854} & \multirow{3}{*}{$\begin{array}{l}\text { Slučajni nacionalni } \\
\text { reprezentativni } \\
\text { uzorak mladih od } \\
12 \text { do } 17 \text { godina }\end{array}$} & Cigarete & $\begin{array}{l}\text { 16,2\% (godišnja prevalencija) } \\
8,9 \% \text { (mjesečna prevalencija) } \\
50,7 \% \text { (godišnja prevalencija) }\end{array}$ \\
\hline & & & & Alkohol & $\begin{array}{c}\text { 29,1\% (mjesečna prevalencija) } \\
\text { 14,8\% (životna prevalencija) }\end{array}$ \\
\hline & & & & Kanabis & $\begin{array}{l}12,7 \% \text { (godišnja prevalencija) } \\
6,8 \% \text { (mjesečna prevalencija) }\end{array}$ \\
\hline \multirow{3}{*}{$\begin{array}{l}\text { CICAD, } \\
2015\end{array}$} & \multirow{3}{*}{$\begin{array}{l}\text { Južna i } \\
\text { Srednja } \\
\text { Amerika } \\
\text { (23 zemlje) }\end{array}$} & \multirow{3}{*}{$\begin{array}{c}\text { Nije } \\
\text { navedeno }\end{array}$} & \multirow{3}{*}{$\begin{array}{l}\text { Nacionalni } \\
\text { reprezentativni } \\
\text { uzorak mladih od } \\
10 \text { do } 19 \text { godine }\end{array}$} & Alkohol & $50 \%$ (mjesečna prevalencija) \\
\hline & & & & Cigarete & 10\% (mjesečna prevalencija) \\
\hline & & & & Kanabis & 5-20\% (godišnja prevalencija) \\
\hline $\begin{array}{l}\text { WHO, } \\
2002\end{array}$ & Južna Afrika & 4325 & $\begin{array}{l}\text { reprezentativan } \\
\text { uzorak mladih od } \\
8 \text { do } 11 \text { razreda }\end{array}$ & Cigarete & $\begin{array}{l}\text { 36,2\% (životna prevalencija) } \\
\text { 14,8\% (mjesečna prevalencija) }\end{array}$ \\
\hline \multirow{3}{*}{ SAMRC, 2013} & \multirow{3}{*}{$\begin{array}{l}\text { Western } \\
\text { Cape } \\
\text { Province, } \\
\text { Afrika }\end{array}$} & \multirow{3}{*}{20227} & \multirow{3}{*}{$\begin{array}{l}\text { reprezentativan } \\
\text { uzorak mladih od } \\
8 \text { do } 10 \text { razreda }\end{array}$} & Duhan & $\begin{array}{c}47,4 \% \text { (životna prevalencija) } \\
40 \% \text { (godišnja prevalencija) } \\
66 \% \text { (životna prevalencija) }\end{array}$ \\
\hline & & & & Alkohol & $\begin{array}{c}\text { 59,1\% (godišnja prevalencija) } \\
\text { 35,1\% (mjesečna prevalencija) } \\
\text { 23,6\% (životna prevalencija) }\end{array}$ \\
\hline & & & & Kanabis & 13\% (godišnja prevalencija) \\
\hline \multirow{4}{*}{$\begin{array}{l}\text { Afolabi i sur., } \\
2012\end{array}$} & \multirow{4}{*}{$\begin{array}{l}\text { Nigerija, } \\
\text { Afrika }\end{array}$} & \multirow{4}{*}{800} & \multirow{4}{*}{$\begin{array}{l}\text { Reprezentativan } \\
\text { uzorak mladih od } \\
12 \text { do } 20 \text { god } \\
\text { Mdob }=13,2 \\
\text { godina }\end{array}$} & Cigarete & $17,6 \%$ (mjesečna prevalencija) \\
\hline & & & & Alkohol & $15,7 \%$ (mjesečna prevalencija) \\
\hline & & & & Kanabis & 1,1\% (mjesečna prevalencija) \\
\hline & & & & Kokain & $5,7 \%$ (mjesečna prevalencija) \\
\hline \multirow{3}{*}{$\begin{array}{l}\text { Li i suradnici, } \\
2013\end{array}$} & \multirow{3}{*}{ Kina, Azija } & \multirow{3}{*}{2668} & \multirow{3}{*}{$\begin{array}{l}\text { Slučajni uzorak } \\
\text { mladih iz Kine od } \\
15 \text { do } 23 \text { godine } \\
\text { Mdob }=17,7 \\
\text { godina }\end{array}$} & Cigarete & $\begin{array}{l}2 \% \text { (posljednja tri mjeseca) } \\
4 \% \text { (posljednja tri mjeseca) }\end{array}$ \\
\hline & & & & Alkohol & 1,4\% (posljednja tri mjeseca) \\
\hline & & & & $\begin{array}{l}\text { Injektiranje droga } \\
\text { Oralna i rinalna uporaba }\end{array}$ & $1,2 \%$ (posljednja tri mjeseca) \\
\hline \multirow{5}{*}{ WHO, 2003} & \multirow{5}{*}{ Tajland } & \multirow{5}{*}{617} & \multirow{5}{*}{$\begin{array}{l}\text { Reprezentativni } \\
\text { uzorak mladih } \\
\text { u dobi od } 10 \\
\text { do } 21 \text { godine } \\
\text { Mdob }=15,1 \\
\text { godina }\end{array}$} & Cigarete & $\begin{array}{c}\text { 32\% (životna prevalencija) } \\
\text { 21,6\% (godišnja prevalencija) } \\
\text { 20,7\% (mjesečna prevalencija) }\end{array}$ \\
\hline & & & & Vino & $\begin{array}{l}\text { 22,5\% (životna prevalencija) } \\
\text { 11,7\% (godišnja prevalencija) } \\
\text { 5,4\% (mjesečna prevalencija) }\end{array}$ \\
\hline & & & & Pivo & $\begin{array}{l}\text { 35,1\% (životna prevalencija) } \\
\text { 23\% (godišnja prevalencija) } \\
15,3 \% \text { (mjesečna prevalencija) }\end{array}$ \\
\hline & & & & Kanabis & $\begin{array}{l}\text { 9\% (životna prevalencija) } \\
\text { 0,9\% (godišnja prevalencija) }\end{array}$ \\
\hline & & & & Amfetamini & $\begin{array}{c}\text { 3,2\% (životna prevalencija) } \\
\text { 1,4\% (godišnja prevalencija) } \\
\text { 0,9\% (mjesečna prevalencija) }\end{array}$ \\
\hline
\end{tabular}


Neven Ricijaš, Valentina Kranželić, Lorena Leskovar: Prevalencija i učestalost konzumiranja...

\begin{tabular}{|c|c|c|c|c|c|}
\hline Autori & Zemlja & Uzorak & $\begin{array}{l}\text { Karakteristike } \\
\text { uzorka }\end{array}$ & Psihoaktivne tvari & Postotak \\
\hline \multirow{5}{*}{ ESPAD, 2012} & \multirow{5}{*}{ Hrvatska } & \multirow{5}{*}{3002} & \multirow{5}{*}{$\begin{array}{l}\text { Stratificirani } \\
\text { slučajni uzorak } \\
\text { učenika } \\
\text { u dobi od } 16 \\
\text { godina }\end{array}$} & Cigarete & $\begin{array}{l}\text { 70\% (životna prevalencija) } \\
41 \% \text { (mjesečna prevalencija) }\end{array}$ \\
\hline & & & & Alkohol & $\begin{array}{l}\text { 93\% (životna prevalencija) } \\
\text { 85\% (mjesečna prevalencija) }\end{array}$ \\
\hline & & & & llegalne psihoaktivne tvari & 19\% (životna prevalencija) \\
\hline & & & & Kanabis & $\begin{array}{l}\text { 18\% (životna prevalencija) } \\
13 \% \text { (mjesečna prevalencija) }\end{array}$ \\
\hline & & & & $\begin{array}{l}\text { Ecstasy } \\
\text { Inhalanti }\end{array}$ & $\begin{array}{l}\text { 2\% (životna prevalencija) } \\
28 \% \text { (životna prevalencija) }\end{array}$ \\
\hline \multirow{6}{*}{ ESPAD, 2016} & \multirow{6}{*}{ Hrvatska } & \multirow{6}{*}{2558} & \multirow{6}{*}{$\begin{array}{l}\text { Stratificirani } \\
\text { slučajni uzorak } \\
\text { učenika } \\
\text { U dobi od } 16 \\
\text { godina }\end{array}$} & Cigarete & $\begin{array}{l}\text { 62\% (životna prevalencija) } \\
33 \% \text { (mjesečna prevalencija) }\end{array}$ \\
\hline & & & & Alkohol & $\begin{array}{l}\text { 92\% (životna prevalencija) } \\
55 \% \text { (mjesečna prevalencija) }\end{array}$ \\
\hline & & & & Ilegalne psihoaktivne tvari & 22\% (životna prevalencija) \\
\hline & & & & Kanabis & 21\% (životna prevalencija) \\
\hline & & & & $\begin{array}{l}\text { Ecstasy } \\
\text { Amfetamini } \\
\text { Metamfetamin } \\
\text { Kokain } \\
\text { LSD } \\
\text { Heroin } \\
\text { GHB } \\
\text { Inhalanti }\end{array}$ & $\begin{array}{l}\text { 2\% (životna prevalencija) } \\
3 \% \text { (životna prevalencija) } \\
1 \% \text { (životna prevalencija) } \\
2 \% \text { (životna prevalencija) } \\
2 \% \text { (životna prevalencija) } \\
1 \% \text { (životna prevalencija) } \\
\text { 1\% (životna prevalencija) } \\
\text { 25\% (životna prevalencija) }\end{array}$ \\
\hline & & & & $\begin{array}{l}\text { Legalne nove psihoaktivne } \\
\text { tvari }\end{array}$ & 7\% (životna prevalencija) \\
\hline
\end{tabular}




\section{Prilog 2.}

Tablični prikaz istraživanja konzumacije psihoaktivnih tvari populacije mladih/adolescenata s problemima u ponašanju (Hammersley, Marslan i Reid, 2003; Horgan, 2013 Kenny i Nelson, 2008; Klatt, 2016; Lebeau-Craven i suradnici 2003; Mulvey i sur., 2010; Ogunwale, 2011; Prichard i Payne, 2005; Putninš, 2001; Youth Justice Board, 2004)

\begin{tabular}{|c|c|c|c|c|c|}
\hline Autori & Zemlja & Uzorak & $\begin{array}{l}\text { Karakteristike } \\
\text { uzorka }\end{array}$ & $\begin{array}{l}\text { Psihoaktivne } \\
\text { tvari }\end{array}$ & Postotak \\
\hline $\begin{array}{l}\text { Hammersley } \\
\text { i sur. } \\
2003\end{array}$ & $\begin{array}{l}\text { Engleska i } \\
\text { Wales }\end{array}$ & $\begin{array}{l}237 \text { mladih } \\
\text { počinitelja/ica } \\
\text { kaznenih djela }\end{array}$ & $\begin{array}{l}\text { Reprezentativni } \\
\text { uzorak populacije } \\
\text { od } 12 \text { do } 18 \\
\text { godina }\end{array}$ & $\begin{array}{c}\text { Alkohol } \\
\text { Cigarete } \\
\text { Kanabis } \\
\text { Ecstasy } \\
\text { Amfetamini } \\
\text { Metadon } \\
\text { Nove } \\
\text { psihoaktivne } \\
\text { tvari }\end{array}$ & $\begin{array}{l}\text { 91\% (životna prevalencija) } \\
\text { 85\% (životna prevalencija) } \\
86 \% \text { (životna prevalencija) } \\
44 \% \text { (životna prevalencija) } \\
41 \% \text { (životna prevalencija) } \\
\text { 8\% (životna prevalencija) } \\
37 \% \text { (životna prevalencija) }\end{array}$ \\
\hline \multirow{8}{*}{$\begin{array}{l}\text { Lader i sur., } \\
2003\end{array}$} & \multirow{8}{*}{$\begin{array}{l}\text { Engleska i } \\
\text { Wales }\end{array}$} & \multirow{8}{*}{$\begin{array}{l}169 \text { mladih } \\
\text { počinitelja } \\
\text { kaznenih djela }\end{array}$} & \multirow{8}{*}{$\begin{array}{l}\text { Reprezentativni } \\
\text { uzorak populacije } \\
\text { od } 16 \text { do } 20 \\
\text { godina }\end{array}$} & Alkohol & $\begin{array}{c}90 \% \text { (godišnja prevalencija - prije ulaska u } \\
\text { zatvor) }\end{array}$ \\
\hline & & & & Cigarete & $\begin{array}{l}\text { 19\% (trenutni konzumenti cigareta) } \\
72 \% \text { (mjesečna prevalencija) }\end{array}$ \\
\hline & & & & $\begin{array}{c}\text { llegalne } \\
\text { psihoaktivne } \\
\text { tvari }\end{array}$ & $\begin{array}{l}\text { 86\% (godišnja prevalencija) } \\
96 \% \text { (životna prevalencija) }\end{array}$ \\
\hline & & & & Kanabis & $\begin{array}{l}\text { 95\% (životna prevalencija) } \\
\text { 78\% (godišnja prevalencija) }\end{array}$ \\
\hline & & & & Heroin & $\begin{array}{l}\text { 34\% (životna prevalencija) } \\
\text { 24\% (godišnja prevalencija) }\end{array}$ \\
\hline & & & & Metadon & $\begin{array}{l}20 \% \text { (životna prevalencija) } \\
8 \% \text { (godišnja prevalencija) }\end{array}$ \\
\hline & & & & Amfetamini & $\begin{array}{l}\text { 62\% (životna prevalencija) } \\
38 \% \text { (godišnja prevalencija) }\end{array}$ \\
\hline & & & & Kokain & $\begin{array}{l}\text { 39\% (životna prevalencija) } \\
26 \% \text { (godišnja prevalencija) }\end{array}$ \\
\hline \multirow{6}{*}{$\begin{array}{l}\text { Horgan, } \\
2013\end{array}$} & \multirow{6}{*}{ Irska } & \multirow{6}{*}{$\begin{array}{c}721 \text { mladi } \\
\text { počinitelj } \\
\text { kaznenih djela }\end{array}$} & \multirow{6}{*}{$\begin{array}{c}\text { Mladi počinitelji } \\
\text { do } 20 \text { godina } \\
\text { pod probacijom, } \\
\text { M i Ž }\end{array}$} & Alkohol & $39,8 \%$ M i 43,6\% Ž (u posljednjih tjedan dana) \\
\hline & & & & Kanabis & $20,4 \%$ M i 14,5\% Ž (u posljednjih tjedan dana) \\
\hline & & & & Ecstasy & 2,6\% M i 1,8\% Ž (u posljednjih tjedan dana) \\
\hline & & & & Amfetamini & 2,1\% M (u posljednjih tjedan dana) \\
\hline & & & & Kokain & 1,7\% M i 1,8\% Ž (u posljednjih tjedan dana) \\
\hline & & & & Metadon & $3,6 \%$ (u posljednjih tjedan dana) \\
\hline \multirow{4}{*}{$\begin{array}{l}\text { Youth Justice } \\
\text { Board, } 2004\end{array}$} & \multirow{4}{*}{ V. Britanija } & \multirow{4}{*}{$\begin{array}{l}511 \text { maloljetnih } \\
\text { počinitelja } \\
\text { kaznenih djela }\end{array}$} & \multirow{4}{*}{$\begin{array}{l}\text { Mladi počinitelji } \\
\text { od } 12 \text { do } 17 \\
\text { godina }\end{array}$} & Kanabis & $\begin{array}{l}\text { 94\% (životna prevalencija) } \\
\text { 83\% (godišnja prevalencija) }\end{array}$ \\
\hline & & & & Ecstasy & $60 \%$ životna prevalencija) \\
\hline & & & & Kokain & 45\% (životna prevalencija) \\
\hline & & & & Heroin & 17\% (životna prevalencija) \\
\hline Klatt, 2016 & Njemačka & $\begin{array}{l}865 \text { mladih } \\
\text { počinitelja } \\
\text { kaznenih djela }\end{array}$ & $\begin{array}{l}\text { Mladi počinitelji } \\
\text { kaznenih djela } \\
\text { iz } 5 \text { institucija u } \\
\text { dobi od } 14 \text { do } 25 \\
\text { godina }\end{array}$ & $\begin{array}{c}\text { llegalne } \\
\text { psihoaktivne } \\
\text { tvari }\end{array}$ & $30 \%$ (mjesečna prevalencija) \\
\hline $\begin{array}{l}\text { Putninš, } \\
2001\end{array}$ & $\begin{array}{l}\text { Adelaide, } \\
\text { Australija }\end{array}$ & $\begin{array}{l}900 \text { mladih } \\
\text { počinitelja } \\
\text { kaznenih djela }\end{array}$ & $\begin{array}{l}\text { Mladi počinitelji } \\
\text { od } 11 \text { do } 20 \\
\text { godina (M i Ž) }\end{array}$ & $\begin{array}{c}\text { Alkohol } \\
\text { Marihuana } \\
\text { Halucinogeni } \\
\text { Sedativi } \\
\text { Narkotici } \\
\text { Stimulansi } \\
\text { Inhalanti }\end{array}$ & $\begin{array}{l}\text { 73\% (mjesečna prevalencija) } \\
81 \% \text { (mjesečna prevalencija) } \\
25 \% \text { (mjesečna prevalencija) } \\
23 \% \text { (mjesečna prevalencija) } \\
10 \% \text { (mjesečna prevalencija) } \\
22 \% \text { (mjesečna prevalencija) } \\
11 \% \text { (mjesečna prevalencija) }\end{array}$ \\
\hline
\end{tabular}


Neven Ricijaš, Valentina Kranželić, Lorena Leskovar: Prevalencija i učestalost konzumiranja...

\begin{tabular}{|c|c|c|c|c|c|}
\hline Autori & Zemlja & Uzorak & $\begin{array}{c}\text { Karakteristike } \\
\text { uzorka }\end{array}$ & $\begin{array}{c}\text { Psihoaktivne } \\
\text { tvari }\end{array}$ & Postotak \\
\hline $\begin{array}{l}\text { Prichard i } \\
\text { Payne, } 2005\end{array}$ & Australija & $\begin{array}{c}371 \text { mladi } \\
\text { počinitelj } \\
\text { kaznenih djela }\end{array}$ & $\begin{array}{c}\text { Mladi počinitelji } \\
\text { KD-a od } 11 \text { do } 17 \\
\text { godina u zatvoru } \\
\text { M i Ž } \\
\text { Mdob }=16 \text { godina }\end{array}$ & $\begin{array}{l}\text { Alkohol } \\
\text { Kanabis } \\
\text { Amfetamini } \\
\text { Inhalanti } \\
\text { Ecstasy }\end{array}$ & $\begin{array}{l}\text { 97\% (životna prevalencija) } \\
94 \% \text { (životna prevalencija) } \\
50 \% \text { (životna prevalencija) } \\
\text { 37\% (životna prevalencija) } \\
33 \% \text { (životna prevalencija) }\end{array}$ \\
\hline $\begin{array}{l}\text { Kenny } \\
\text { iNelson, } \\
2008\end{array}$ & $\begin{array}{l}\text { Južni Wales, } \\
\text { Australija }\end{array}$ & $\begin{array}{c}800 \text { mladih } \\
\text { počinitelja } \\
\text { kaznenih djela }\end{array}$ & $\begin{array}{l}\text { Mladi počinitelji } \\
\text { kaznenih djela na } \\
\text { probaciji (M i Ž) } \\
\text { Mdob }=17 \text { godina }\end{array}$ & $\begin{array}{l}\text { Alkohol } \\
\text { Cigarete } \\
\text { Kanabis } \\
\text { Amfetamini } \\
\text { Kokain } \\
\text { Heroin }\end{array}$ & $\begin{array}{l}\text { 97\% (životna prevalencija) } \\
\text { 81\% (životna prevalencija) } \\
\text { 89\% (životna prevalencija) } \\
46 \% \text { (životna prevalencija) } \\
\text { 18\% (životna prevalencija) } \\
\text { 14\% (životna prevalencija) }\end{array}$ \\
\hline $\begin{array}{l}\text { Mulvey i sur., } \\
2010\end{array}$ & $\begin{array}{l}\text { Philadelphia i } \\
\text { Phoenix, SAD }\end{array}$ & $\begin{array}{l}\text { 1v354 mladih } \\
\text { počinitelja } \\
\text { kaznenih djela }\end{array}$ & $\begin{array}{l}\text { Mladi počinitelji } \\
\text { kaznenih djela od } \\
14 \text { do } 17 \text { godina }\end{array}$ & $\begin{array}{l}\text { Alkohol } \\
\text { Kanabis } \\
\text { Halucinogeni } \\
\text { Kokain } \\
\text { Sedativi } \\
\text { Stimulansi } \\
\text { Inhalanti } \\
\text { Opijati } \\
\text { Ecstasy }\end{array}$ & $\begin{array}{c}\text { 80\% (životna prevalencija) } \\
\text { 85\% (životna prevalencija) } \\
25 \% \text { (životna prevalencija) } \\
23 \% \text { (životna prevalencija) } \\
21 \% \text { (životna prevalencija) } \\
15 \% \text { (životna prevalencija) } \\
\text { 13\% (životna prevalencija) } \\
7 \% \text { (životna prevalencija) } \\
\text { 16\% (životna prevalencija) }\end{array}$ \\
\hline $\begin{array}{l}\text { Lebeau- } \\
\text { Craven i sur., } \\
2003\end{array}$ & SAD & $\begin{array}{c}186 \text { mladih } \\
\text { počinitelja } \\
\text { kaznenih djela }\end{array}$ & $\begin{array}{c}\text { Mladi počinitelji } \\
\text { kaznenih djela od } \\
13 \text { do } 20 \text { godine } \\
\text { u zatvoru M } \\
\text { Mdob }=17 \text { godina }\end{array}$ & $\begin{array}{l}\text { Alkohol } \\
\text { Kanabis }\end{array}$ & $\begin{array}{c}\text { 84,9\% (mjesečna prevalencija) } \\
\text { 46\% (mjesečna prevalencija) }\end{array}$ \\
\hline $\begin{array}{l}\text { Ogunwale, } \\
2011\end{array}$ & Nigerija,Afrika & $\begin{array}{c}54 \text { mladih } \\
\text { počinitelja } \\
\text { kaznenih djela }\end{array}$ & $\begin{array}{l}\text { Mladi počinitelji } \\
\text { kaznenih djela } \\
\text { Mdob }=18,6 \\
\text { godina }\end{array}$ & $\begin{array}{l}\text { Alkohol } \\
\text { Kanabis }\end{array}$ & $\begin{array}{l}66,7 \% \text { (Životna prevalencija) } \\
48,1 \% \text { (životna prevalencija) }\end{array}$ \\
\hline
\end{tabular}




\title{
Prevalence and the frequency of psychoactive substances consumptions of youth in educational institutions - differences with regards to the type of institution and knowledge about psychoactive substances
}

\begin{abstract}
Studies confirm that adolescents experiment with the consumption of psychoactive substances during their growth, while the main motivational processes are related to their desire to behave in accordance with social norms, an identity that identifies individuality, escape from discomfort and self-regulation. Research of correlation between attitudes, beliefs, and knowledge about psychoactive substances with behaviour related to their use showed a weak to moderate correlation. The main aim of this study was to gain insight into the frequency of consumption of psychoactive substances of young people with behavioural problems placed in educational institutions, while the specific objectives were to investigate the differences in the frequency of consumption with regard to the type of institution as well as the level of knowledge about psychoactive substances

A total of $\mathrm{N}=74$ young men participated in the study placed in the justice system institution $(39,2 \%)$ and social welfare institution (60,8\%). The age of the participants ranges from 14 to 21 years of age (Mage=16,90, SDage=1,627). With the basic socio-demographic data, the instrument measured knowledge about psychoactive substances, as well as the life and year prevalence and the frequency of the consumption.

The results show a somewhat more frequent consumption of psychoactive substances among youngsters institutionalized within the justice system, but also among participants with a higher level of knowledge of psychoactive substances. It is important to emphasize that the effects of differences are low to moderate. The results are interpreted in the context of other domestic and foreign prevalence studies and in view of the importance of knowledge in creating interventions for young people in the area of the prevention of psychoactive substances consumption.
\end{abstract}

Keywords: psychoactive substances, drugs, behavioural problems, adolescents, educational institutions 